\title{
The influence of shortening and sedimentation on rejuvenation of salt diapirs: A new Discrete-Element Modelling approach
}

DOI:

10.1016/j.jsg.2017.09.016

\section{Document Version}

Accepted author manuscript

Link to publication record in Manchester Research Explorer

Citation for published version (APA):

Muniz Pichel, L., Finch, E., Huuse, M., \& Redfern, J. (2017). The influence of shortening and sedimentation on rejuvenation of salt diapirs: A new Discrete-Element Modelling approach. Journal of Structural Geology, 104, 6179. https://doi.org/10.1016/j.jsg.2017.09.016

Published in:

Journal of Structural Geology

\section{Citing this paper}

Please note that where the full-text provided on Manchester Research Explorer is the Author Accepted Manuscript or Proof version this may differ from the final Published version. If citing, it is advised that you check and use the publisher's definitive version.

\section{General rights}

Copyright and moral rights for the publications made accessible in the Research Explorer are retained by the authors and/or other copyright owners and it is a condition of accessing publications that users recognise and abide by the legal requirements associated with these rights.

\section{Takedown policy}

If you believe that this document breaches copyright please refer to the University of Manchester's Takedown Procedures [http://man.ac.uk/04Y6Bo] or contact uml.scholarlycommunications@manchester.ac.uk providing relevant details, so we can investigate your claim.

\section{OPEN ACCESS}




\section{Accepted Manuscript}

The influence of shortening and sedimentation on rejuvenation of salt diapirs: A new Discrete-Element Modelling approach

Leonardo M. Pichel, Emma Finch, Mads Huuse, Jonathan Redfern

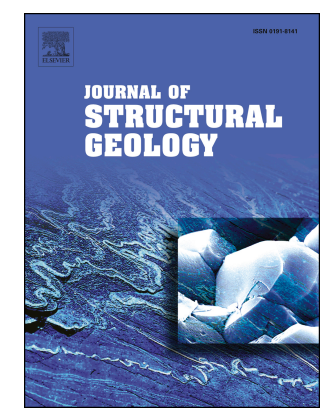

PII:

S0191-8141(17)30202-X

DOI:

10.1016/j.jsg.2017.09.016

Reference: $\quad$ SG 3534

To appear in: Journal of Structural Geology

Received Date: 19 June 2017

Revised Date: 20 September 2017

Accepted Date: 29 September 2017

Please cite this article as: Pichel, L.M., Finch, E., Huuse, M., Redfern, J., The influence of shortening and sedimentation on rejuvenation of salt diapirs: A new Discrete-Element Modelling approach, Journal of Structural Geology (2017), doi: 10.1016/j.jsg.2017.09.016.

This is a PDF file of an unedited manuscript that has been accepted for publication. As a service to our customers we are providing this early version of the manuscript. The manuscript will undergo copyediting, typesetting, and review of the resulting proof before it is published in its final form. Please note that during the production process errors may be discovered which could affect the content, and all legal disclaimers that apply to the journal pertain. 

Diapirs: a new Discrete-Element Modelling Approach

71 - School of Earth and Environmental Sciences, University of Manchester, Oxford 8 Road, Manchester M13 9PL, UK

92 - North Africa Research Group, University of Manchester, Oxford Road,

10 Manchester M13 9PL, UK

11 Corresponding author: leonardo.munizpichel@manchester.ac.uk

$12+44(0) 7479011308$

13 Emma.finch@manchester.ac.uk

14 Mads.huuse@manchester.ac.uk

15 Jonathan.redfern@manchester.ac.uk

17 Key-words: SALT TECTONICS, DISCRETE-ELEMENT MODELLING, SALT

18 TONGUE, TEAR-DROP, DIAPIR 
This study employs a novel Discrete-Element Modelling approach to investigate the interplay of sedimentation with rejuvenation of diapirs by shortening. The inherent complexity of salt tectonics, the complications encountered when imaging structures beneath salt, and the lack of outcrop analogues, coupled with its importance to petroleum systems, make salt tectonics one of the most interesting and debated topics in basin studies. Model results successfully reproduce the geometric and dynamic behaviour of active diapirism and show the effects of sedimentation thickness, rate and timing on the generation of distinct diapir geometries, including i) salt tongues and ii) squeezed upright diapirs. Models with late sedimentation or a lower sedimentation rate relative to salt mobility show development of asymmetric diapirs with allochthonous salt tongues; whereas models with earlier sedimentation or a faster sedimentation rate generate upright squeezed diapirs. Early sedimentation at a moderate rate results in a symmetrical hour-glass shaped structure, resembling a tear-drop diapir. Results are fully reproducible and comparable with many natural examples, and include overburden deformation which deformation mechanisms and sediment distribution around salt structures. 
Salt is an incompressible material with negligible yield strength that behaves as a viscous fluid under typical geological strain rates (e.g. Turcotte and Schubert, 2002; Hudec and Jackson, 2007). The mechanical instability of evaporites, herein referred to as salt, allows it to be more easily deformed than any other rock and to produce some of the most spectacular structures found in sedimentary basins (Fig. 1a and b).

Salt tectonics acts as a major control on the geological and structural evolution of more than 120 basins around the world (Hudec and Jackson, 2007). Most of these basins are prolific hydrocarbon provinces e.g. the Gulf of Mexico (e.g. Schuster, 1995; Rowan 1995; Rowan et al., 2000; Hudec and Jackson, 2009; Hudec et al., Huuse, 2015).

Rejuvenation of diapirs is a common phenomenon of salt basins around the world and is commonly driven by regional shortening. On continental margins, regional shortening can be caused by gravity-driven salt tectonics, such as in Angola (Hudec and Jackson, 2004), Brazil (Quirk et al., 2012; Fiduk and Rowan, 2012), Nova Scotia 
78 (Albertz et al., 2010) and the Gulf of Mexico (Rowan et al., 2000; Hudec et al., 2013)

or by its combination with thick-skinned crustal tectonics as in NW Africa (Davison, 2005; Tari and Jabour, 2013; Tari et al., 2017), the North Sea (Davison et al., 2000; Harding and Huuse, 2015), the Parentis Basin (Ferrer, et al., 2012), and the Gulf of Cadiz (Matias et al., 2011) Some of the most successful salt-related hydrocarbon plays along these margins occur associated with salt structures that were reactivated by shortening, such as the flank-of-diapir play in the Central Graben in the North Sea, examples including Banff, Mashar, Monan, Pierce and many other discoveries in the flanks of squeezed upright diapirs worldwide (Davison et al., 2000; Birch and Haynes, 2003), and sub-salt plays beneath allochthonous salt tongues and sheets, such as the Ship Shoal and Mahogany oil fields in the Gulf of Mexico, plays that host considerable volumes of hydrocarbons, and are becoming increasingly important as seismic imaging methods improve (Montgomery and Moore, 1997).

Shortening of salt stocks and walls displaces salt, and can result in pinching-off of their necks with complete exhaustion of salt supply and the development of subvertical salt-welds and dramatic structures such as tear-drop diapirs and allochthonous salt tongues (Fig. 1a-b; Hudec and Jackson, 2007, 2011). Tear-drop diapirs (Fig. 1b) have an hourglass shape in which a symmetric salt bulb is separated from its pedestal and source-layer by a (sub) vertical salt weld (Nilsen and Vendeville, 1995; Hudec and Jackson, 2007). Salt tongues (Wang, 1988; Hudec and Jackson, 2007; Tari and Jabour, 2013) may also have a squeezed sub-vertical feeder but differ from tear-drop diapirs, mainly because their asymmetric upper salt body has a larger seaward overhang compared to a smaller or non-existent landward overhang which results in emplacement of allochthonous salt at a higher stratigraphic level (Fig 1a and 4b). Allochthonous salt tongues may also develop due 
to differential loading (Schuster, 1995; Rowan, 1995) whereas tear-drop diapirs form exclusively by lateral shortening.

\section{Figure 1 here}

Although the development of tear-drop and squeezed diapirs is relatively well-known, the evolution of salt tongues and sheets and their interaction with sedimentation is still poorly understood. Some authors (McGuinnes and Hossack, 1993; Talbot, 1993; Fletcher et al., 1995; Rowan and Inmann, 2011) consider they form due to salt extrusion at the paleo sea-floor, whereas others argue that they are formed by contractional reactivation of buried salt structures and thrust piercement of salt (Nelson and Fairchild, 1989; Wu et al., 1990; Tari et al., 2003; Hudec and Jackson, 2007; Tari and Jabour, 2013; Jackson et al., 2015). The impact of sedimentation on the rejuvenation of diapirs and on the generation of these distinct geometries (e.g. symmetric diapirs and salt tongues) is still not fully understood.

The lack of good and accessible outcrop analogues of salt structures at the scale of an entire diapir, problems with seismic imaging linked with the high velocities associated with salt, the complex geometries encountered (Fig. 1a and b) and its unique mechanical behaviour make the interpretation of salt tectonics and its interaction with surrounding sediments and basement structures challenging. In this context, physical and numerical forward modelling techniques are useful tools that help improve understanding of the kinematic and mechanical behaviour of salt.

The latest finite-element models (FEM), based on arbitrary Lagrangian-Eulerian formulations (Gemmer et al., 2004, 2005; Albertz and Ings, 2012; Gradmann et al., 2009; Gradmann and Beaumont, 2016) provide successful and numerically accurate results of local and regional scale salt tectonics (Fig. 1c). Their reproducibility and 
more precise control on numerical parameters have significant advantages over physical models, but they prevent observation of realistic deformational processes in the overburden, such as brittle deformation, as they treat it as a continuous frictionalplastic and often viscous-plastic material (Fig.1c). Other limitations of FEM are that points are fixed in their respective temporal and spatial positions while the grid moves and it requires regular re-meshing (Schultz-Ela et al., 1993; Fullsack, 1995), a relatively computationally intense process necessary within deformed areas.

Physical models typically using silicone polymers and sand to simulate salt and overburden and have been very efficient in modelling salt tectonics at regional and small scales in both 2D and 3D (Fig. 1d), increasing our current knowledge of salt tectonics by producing geometrically accurate and naturalistic results. There are few drawbacks, however, with this technique due to the amount of time and financial investment required for each experiment and, even though they are reasonably reproducible on a large scale, repeated experiments are not exactly identical in a finer scale as in numerical methods (Botter et al., 2014), which involve more control on physical parameters and can allow tracking of individual particles and forces in the system through time.

Due to the predominant focus of the hydrocarbon industry in understanding reservoir distribution and compartmentalization around salt structures, a novel approach has been applied in this study. A Discrete-Element Modelling (DEM) technique has been developed to investigate the interplay between rejuvenation of diapirs by shortening and deep-water sedimentation. The ultimate goals of this study are: i) to evaluate how active diapirism controls sediment distribution and overburden deformation; ii) to assess how aggradation affects diapir geometry on a slope setting; and ii) to test the 
151 feasibility of DEM for salt studies, by comparing results with natural examples and commonly used physical and numerical analogues.

153 DEM is a discontinuous method in which the viscous behaviour of salt is approximated. Here, it is considered a complementary solution to other modelling techniques as it produces physically realistic and relatively fast results that provide new and valuable insights of the sequential evolution of salt diapirs and how they interact with sedimentation and deformation in the overburden.

\section{Methodology}

\subsection{Discrete-Element Modelling Principles}

160 The Discrete-Element Modelling (DEM) applied here is a discontinuous numerical method derived from the Lattice Solid Model (LSM) from Mora and Place (1993, 1994) and Place et al. (2002) and the Particle Dynamics Method. This technique has been used extensively in physics and chemistry to simulate liquid and gas behaviours (Allen and Tildesley, 1987; Hardy and Finch, 2006). Most recently, it has been successfully applied in simulation and modelling of the dynamic evolution of natural geological systems (Donzé et al., 1993; Place et al., 2002), and to investigate faulting and folding processes (Finch et al., 2003, 2004; Hardy and Finch 2005, 2006, 2007; Schöpfer, 2006) as well as viscous flow of rock matrices (Abe and Urai, 2012).

As with any other modelling approach, DEM has limitations, such as the limited number of particles and duration of simulations (Zhu et al., 2008) and the need of meticulous calibration of particle parameters (Botter et al., 2014), but it offers the

173 following advantages over other methods:1) scale is not a restriction, 2) results are 
easily reproducible, 3) it does not require complex re-meshing and extraction of temporal and spatial information to track individual elements since each computing step registers position and velocities of elements within the system; and 4) it is intrinsically discontinuous and each element simulates the physical properties of a rock. These factors make DEM an ideal method to quantitatively study overburden deformation.

DEM treats the rock mass as an assemblage of circular elements that interact in pairs connected by breakable elastic springs through a 'repulsive-attractive' force obeying Newton's Laws of motion (Mora and Place, 1993, 1994; Finch et al., 2004; Hardy and Finch, 2006). The relative strength of the assemblage is defined by its breaking separation so the particles remain bonded until this threshold is exceeded (Donzé et al., 1994; Finch et al., 2004). The force acting on a bond at this threshold corresponds to the force necessary for failing or yielding of the bond, representing the stress acting on a particle at failure (Hardy and Finch, 2005). Once a bond is broken, the elements that it connects experience no further attractive force. If the elements return to a compressive contact however, a repulsive force acts between them. Thus, healing of bonds is not allowed in this methodology (Finch et al., 2003, 2004; Hardy and Finch, 2006). The motion of elements is assumed to be frictionless and cohesionless with elasto-plastic behaviour (Finch et al., 2003; Hardy and Finch, 2007).

The circular elements in these models have four different radii of $0.2,0.3,0.4$ and 0.5 units which are randomly distributed to reduce failure in preferential orientations within the matrix. A viscous term $(\dot{v})$ is added to counteract the elastic behaviour of the springs and the build-up of kinetic energy within a closed system. This viscosity rapidly dissipates energy and damps reflected waves from the model boundaries, 
reducing dynamic phenomena and thermal vibrations, and enabling the stabilization of the model (Finch et al., 2004), making it ideal for the study of tectonic processes.

201 Forces are resolved in both $\mathrm{x}$ and $\mathrm{y}$ directions and, as the elements are also subjected to gravitational forces, $F_{g}$, the equations that define the inter-relationship of all forces acting on the DEM are:

$204 \quad F_{x}=F_{i, n}-v \dot{x}$

$205 \quad F_{y}=F_{i, n}-v \dot{y}+F_{g}$

Where $F_{i, n}$ corresponds to the total elastic force acting on a particle, $v$ represents the dynamic viscosity and $\dot{x}$ and $\dot{y}$ correspond to the velocity of the particle. For a complete and more detailed description of scaling of parameters and the equations governing DEM, see Mora and Place (1994), Finch et al. (2004) and Hardy and Finch $(2005,2006)$.

\subsection{Discrete-Element Modelling of Salt Tectonics}

212 Because of its discontinuous nature, DEM has not yet been used to analyse salt213 related deformation. Nevertheless, Abe and Urai (2012) applied it successfully to reproduce the viscous behaviour of boudinage matrix flow, showing that the methodology can be efficient to model viscous-plastic materials. In order to make DEM applicable to salt tectonics, the properties of the elements representing salt are adjusted so they behave macroscopically as a viscous-plastic material and deform microscopically by an approximation of dislocation-creep, which is expected for dry rock-salt (Urai et al., 1986; Spiers et al., 1990). This does not reproduce entirely the mechanical behaviour of salt in nature, which usually contains traces of brine (Urai et al., 1986) and deforms on the threshold of diffusion and dislocation creep (Spiers et 
al., 1990; Jackson and Hudec, 2017) but, based on the stress-strain response obtained in our study (Fig. 2), it works as a good first-order approximation.

\section{Figure 2 here}

225 This approximation of the mechanical behaviour of rock-salt is achieved by reducing

226 the breaking separation of particles representing salt to the point that they deform plastically and are controlled entirely by the viscosity and gravity of the system, thus exhibiting macroscopic viscous-plastic behaviour. In order to achieve this, a range of breaking separations was tested using biaxial compressional tests and extracted differential stress-strain plots. Here, the results from experiments with materials that reproduced the expected mechanical behaviour of salt and the overburden are presented, which have 0.001 and 0.05 of separation threshold respectively (Fig. 2).

The tests show that a media with a separation threshold of 0.05 is relatively weak but still develops well-defined fault segments (Fig. $2 a$ and b) and produces a stressstrain response typical of brittle materials with an initial elastic (upward segment) and a later brittle component (downward segment) (Fig. 2c); whereas materials with breaking separation of 0.001 react with non-localized and pervasive breaking of bonds (Fig. 2a and b), and generate a linear and horizontal response with insignificant elastic component, representative of ductile viscous-plastic materials that accumulate strain without significant variations of stress (Fig. 2c). This response pattern of materials representing rock-salt is very similar to the curves produced by physical (Spiers et al., 1990) and numerical (Li and Urai, 2016) experiments of salt deformation, demonstrating rheological similarity (Weijermars and Schmeling, 1985; Weijermars et al., 1993). 
Since the breaking separation of salt and, consequently, its elastic force component are negligible (e.g. $F_{i, a} \approx 0$ ), the forces acting on the salt are dependent on its viscosity and the gravity of the system. Hence, the real-world scale viscosity of the salt is $1.14 \times 10^{9}$ Pa.s, which is lower than its real world viscosity $\left(10^{17}-10^{18}\right.$ Pa.s Turcotte and Schubert, 1982; Hudec and Jackson, 2007) but is still a reasonable approximation when compared with physical models, in which scaling is applied but salt is modelled using silicon polymers with viscosities in the range of $10^{4}$ Pa.s (Vendeville et al., 1995; Ge et al., 1997; Dooley et al., 2009, 2012; Brun and Fort, 2011; Adam and Krezsek, 2012).

\subsection{Modelling Scenario and Experimental Parameters}

A series of experiments on the rejuvenation of buried diapirs by regional shortening in a deep-water setting were conducted with the following objectives: i) to analyse the effects of sedimentation on the rejuvenation of salt structures driven by shortening; and, ii) to understand how salt movement controls depocentre distribution and deformation. It is not intended in this work to investigate the initial stages of evolution of diapirs as this has been already extensively studied (Trusheim, 1960; Vendeville and Jackson, 1992; Vendeville, 2002; Hudec and Jackson, 2007).

The modelled media consists of a box (Fig. 3) with a rigid and undeformable base and free side-walls and 10894 elements with varying radii. The media represents a length of $9.8 \mathrm{~km}$ and height of $1.5 \mathrm{~km}$ with a $3^{\circ}$ bas inward dip to simulate margin tilting due to post-rift thermal subsidence. This dip fits within the spectrum of salt detachment slopes at deep-water segments of many continental margins salt basins (Tari et al., 2003; Peel 2014) and is within the range used in previous models of salt tectonics (Brun and Fort, 2011; Dooley et al. 2007; Dooley et al., 2015). 
270 It is assumed that an earlier phase of diapirism is responsible for the emplacement of

a wide and symmetric salt stock with relatively little deformation of the adjacent minibasins as expected for a passive mode of diapirism (Vendeville and Jackson, 1992a; Hudec and Jackson, 2007; Weijermars et al., 2015). Thus, the salt stock is $1.25 \mathrm{~km}$ wide and $1.25 \mathrm{~km}$ (10 layers) high, with steep flat walls and un-deformed pre-kinematic overburden, the autochthonous salt and the diapir roof are 2 layers $(250 \mathrm{~m})$ thick and pre-kinematic sediments are 10 layers thick $(1.25 \mathrm{~km})$. A different colour is assigned to each pre- and syn-kinematic layer so overburden deformation can be easily tracked. Four markers were included within the stock and 2 markers in the source-layer to investigate intra-salt flow (Fig. 3).

The flat crest in cross-section reproduces dissolution effects prior to its burial, a common characteristic of many natural examples of buried diapirs (Schultz-Ela et al., 1993; Jackson et al., 2015). Although variations of source-layer thickness in the peripheral sinks of passive diapirs occur (Vendeville and Jackson, 1992a, Hudec and Jackson, 2007), for design simplicity and because the focus of this paper is on the late evolution and rejuvenation of diapirs, this interval is modelled as initially isopachous, similar to previous physical models studies (Dooley et al., 2009, 2015, models 5-7).

For simplicity, an homogeneous overburden is assumed, with density of $2300 \mathrm{~kg} \mathrm{~m}^{-3}$, representative of sediments not heavily compacted, and salt density of $2160 \mathrm{~kg} \mathrm{~m}^{-3}$, representative of mobile salt, i.e. halite (Albertz and Ings, 2012; Gradmann and Beaumont, 2016), which is the main component of diapirs since the less mobile evaporites are preferentially left behind in the autochthonous layer as the structure 
293 develops (Kupfer, 1968; Wagner and Jackson, 2011; Albertz and Ings, 2012;

294 Cartwright et al., 2012; Dooley et al., 2015). Both densities are in agreement with previous physical and numerical analogues and natural examples (Gemmer et al., 2005; Ings and Shimmeld, 2006; Dooley et al., 2009, 2012, Albertz and Ings, 2012;

297 Gradmann and Beaumont, 2016). As both the thickness and density ratios of our models and natural prototypes are similar, stress in the elasto-plastic overburden are dynamically scaled (Weijermars et al., 1993).

The Poisson's ratio (v) for 2D DEM models is 0.33 and the Young Modulus (E) of salt and overburden are 3.65 and $13.5 \mathrm{GPa}$ respectively, which are in the range of natural examples of salt and an overburden formed by sandstones and mudstones (Johnson and DeGraff, 1988; Liang et al., 2007).

Contacts at the boundary walls are exclusively compressional. Experiments are run for a total of 5 million time-steps divided equally into 5 phases (I to V). The model run-time has been scaled to simulate strain and sedimentation rates that are compatible to natural examples. Thus, in this case each time-step is equivalent to 2 years and each phase corresponds to $2 \mathrm{Ma}$. Regional compression is simulated by inward movement of both end-walls at a constant displacement rate of $0.39 \mathrm{~mm} / \mathrm{year}$ and $8 \%$ compression per 2 Ma phase. Hence, compression generates a total displacement of $3.9 \mathrm{~km}$ or $40 \%$ of compression at a strain rate of $2.5 \times 10^{-5} \mathrm{~s}^{-1}$, in the range of ductile strain rates of salt deformation in nature (Weijermars et al., 1993; Jackson and Hudec 2017). The amount of shortening of deep-water contractional domains in passive margins varies considerably from 5-6 km in the Mississippi Fan and Perdido Fold-Belt, Gulf of Mexico, 27-30 km in the Kwanza Basin, Angola, to $100 \mathrm{~km}$ in the Campos Basin with shortening rates in the range of $0.1-0.5 \mathrm{~mm} /$ year 
318 A series of 5 experiments were conducted where the timing, thickness and rate of sedimentation were varied to investigate the interplay of sediment input with the rejuvenation of diapirs. Sediments are added to the system following a fill-to-spill methodology relative to a base-level that progressively rises $50 \mathrm{~m}$ during the sedimentation interval, simulating pelagic aggradation. Sedimentation frequency has been defined at a constant rate of $0.125 \mathrm{~m} / \mathrm{ka}$ for models 1 to 3 and 0.1 and 0.15 $\mathrm{m} / \mathrm{ka}$ for models 4 and 5, respectively, which are within the range of Cenozoic sedimentation rates for the Atlantic Ocean (Whitman and Davies, 1979) and previous numerical models of salt tectonics (Hardy and Cohen, 1996; Gemmer et al., 2005). Syn-kinematic material consists of smaller elements with variable radii size to prevent development of unrealistic holes and facilitate visualization of structures. All other properties are the same as the pre-kinematic material.

\section{Model Results}

331 Table 1 summarizes differences in sedimentation patterns and resultant diapir 332 geometries for each model. Model 1 is run without syn-kinematic sedimentation whereas for models 2 and 3, syn-kinematic sedimentation occurs at a constant rate of $0.125 \mathrm{~m} / \mathrm{Ka}(250 \mathrm{~m} / \mathrm{phase})$. In model 2, sedimentation starts late (beginning of phase IV) and reaches a total thickness of $500 \mathrm{~m}$ and in model 3, sedimentation starts earlier (beginning of phase II), reaching a thickness of $1000 \mathrm{~m}$ (Table 1). Thus, by comparing models $1-3$, the effects of the timing and thickness of sedimentation on diapir evolution are evaluated (section 3.1).

For models 4 and 5, the rate of sedimentation is changed to $0.1 \mathrm{~m} / \mathrm{Ka}(200 \mathrm{~m} / \mathrm{phase})$ and $0.15 \mathrm{~m} / \mathrm{ka}$ (300 m/phase), respectively. All other parameters remain the same as 
model 3 to allow comparison of the effects of sedimentation rates on active diapirism driven by shortening.

\subsection{Influence of Timing and Thickness of Sedimentation on Salt Mobilization} and Geometry (Models $1-3$ )

\subsubsection{Model 1: No Syn-kinematic Sedimentation}

During Phase I, the experiment shows incipient squeezing of the diapir with minor salt upwelling generating gentle uplift and arching of the roof. Salt anticlines develop at the edges of the model folding the overburden (Fig. 4a). During Phase II (Fig. 4b), salt anticlines are amplified, the diapir gets progressively thinner and taller. Small reverse faults appear in the form of symmetric pop-up structures (PP1-PP3) towards the top of the pre-kinematic cover, which are attributed to free-surface effects. Due to continuous salt inflation, a basinward-vergent thrust (RT1) forms on the roof of the diapir favouring upward and basinward salt flow along the base of the hanging-wall.

Figure 4 here

In Phase III (Fig. 4c), the diapir continues to inflate and push its roof upwards due to increasing upward salt flow driven by shortening. Movement is accommodated by the development of roof-thrusts, which occur mainly at the diapir margins (ET 1-2) but also immediately above the diapir's centre (RT1). The downdip thrust (ET1) allows basinward salt movement and the formation of an immature salt tongue by thrust advance. Amplification of the distal salt pillow culminated with the formation of a large front-thrust (FT1) at its crest and thrust piercement of salt (sensu Hudec and Jackson, 2007) at the base of its hanging wall as in the source-fed thrust mechanism 
364 (sensu Hudec and Jackson, 2006), in which salt is carried up along the fault plane,

365

366

367

368

conformably to hanging-wall strata and unconformably to the footwall (Hudec and Jackson 2007). The development of this structure is partly due to edge-effects from the downdip end-wall but also to continuous inflation and shortening of the salt pillow. New reverse faults, such as FT2 and back-thrust (BT1) developed while previous faults enlarged and rotated (Phase III, fig. 4c).

During Phase IV, the diapir's roof started to undergo outer-arc extension in response to increasing salt upwelling progressively pushing the roof upwards (Fig 4d). Uplift was preferentially accommodated along the basinward roof-edge thrust (ET1) in response to the basinward tilting of the margin, while there was only minor salt flow on the hanging-wall of the landward-vergent roof-edge thrust (ET2) on the opposite flank of the diapir.

In Phase V (Fig. 4e), the stock was laterally shortened to $280 \mathrm{~m}$, equivalent to $22 \%$ of its original width, leading to further asymmetric upwelling and inflation of the salt tongue. The final salt structure is $2 \mathrm{~km}$ high, $750 \mathrm{~m}$ taller than its initial configuration, and has a small basinward salt tongue $750 \mathrm{~m}$ wide, similar to examples from West Africa continental margins (e.g. Tari and Jabour 2013; Tari et al., 2017). An imbricate thrust-system (ITS), similar to Hudec and Jackson (2009), formed immediately basinward of the salt tongue as it spread horizontally and reached a buttress formed by the uplifted and rotated pop-up block (PP1, Fig. 4e).

This model shows that as salt was squeezed from the stock, it became pressurized and rose, initially arching and elevating its roof above the regional datum (Fig. 4a, b) and then, dismembering and rotating it outwards (Fig. 4c-e) with the development of normal keystone faults by outer-arc stretching. This is the pattern expected for 
forceful intrusion or active diapirism driven by regional shortening (Schultz-Ela et al., 1993; Hudec and Jackson, 2007; Dooley et al., 2015; Rowan et al., 2016). In our model, however, piercement was asymmetric and resulted in basinward advance of salt forming a small salt tongue similar to the plug-fed mechanism (sensu Hudec and Jackson, 2006) due to: a) the lack of syn-kinematic sediments; b) the topographic slope of the system generating an elevation head on top of the diapir (Weijermars et al., 2015; Dooley et al., 2015); and c) the position of the diapir slightly close to the updip end-wall (although this is of secondary importance). This asymmetric piercement caused the basinward flap to be more intensely uplifted, rotated and completely shouldered aside (Fig. 4e). The landward flap was initially rotated outward (Fig. 4b-c) but began to rotate inward as salt started to flow on the hangingwall of the roof-edge thrusts ET1-2 (Fig. 4d-e).

The overall thickness of the source-layer did not change considerably as there was no sedimentation to impose differential sedimentary loading onto it and regional shortening balanced localized salt expulsion by thickening the salt layer (Jackson and Hudec, 2017) and by promoting minor inward salt flow from the diapir into the source-layer as proposed by Dooley et al., (2009).

\subsubsection{Model 2: Influence of Late Sedimentation}

In the second experiment, syn-kinematic sedimentation occurs during the two last phases (IV-V) and is equivalent to a maximum of $500 \mathrm{~m}$ of sediment aggrading around the diapir. During Phases I-III, model evolution is identical to Model 1 (Fig. $4 a-c)$ and it changes only at the moment that sedimentation commences (Fig. 5b-c). To avoid repetition, only images of the final three phases are presented: Phase III, where evolution is identical to Model 1 (Fig. 5a) and Phases IV and V, in which 
412

413

414

415

416

417

418

419

420

421

422

423

424

425

426

427

428

429

430

431

432

433

434

system evolution is different (Fig. 5b-c). Due to the basinward tilting of the margin, and the relief at the sea-floor produced by the diapir at the end of Phase III, an earlier and thicker depocentre is generated on its basinward flank which retards basinward salt flow and results in a more symmetric structure with a narrower basinward tongue of $485 \mathrm{~m}$ (Fig. 5c) compared with $750 \mathrm{~m}$ when sedimentation is not present (Fig. 4e).

\section{Figure 5 here}

The addition of sediment around the salt structure gently increases differential loading, enhancing salt expulsion from the source-layer and inflation of the diapir. The final structure is $950 \mathrm{~m}$ or $76 \%$ taller than its initial geometry and $200 \mathrm{~m}$ taller with a feeder $20 \mathrm{~m}$ wider than the diapir in Model 1 without sedimentation (compare Figs. $4 \mathrm{e}$ and $5 \mathrm{c}$ ). The source-layer in Model 2 is, on average, only $15 \mathrm{~m}$ thinner than in Model 1 (white tick on the source-layer landward of the diapirs in Models 1 and 2, Figs. $4 \mathrm{e}$ and $5 \mathrm{e}$ ), and is locally thicker at the basinward side due to higher structural loading in Model 1 by the imbricate thrust-system and the upturn of the hanging-wall block above FT2 (Fig. 4e).

A greater depocentre thickness and salt inflation allowed the development of a second basinward roof-edge thrust (ET3, Fig. 5c) immediately above ET1. As the lower part of the sheet was being buttressed by a thicker and stronger overburden (relative to Model 1) salt was forced to climb higher, resulting in stronger basinward flow towards the top of the inflating salt tongue. The flaps rotate less than in Model 1 although arching and rotation were still enough to stretch the roof horizontally and produce a set of keystone normal faults (Fig. 5c). As sediments were deposited they were folded and faulted by the propagation of roof-edge thrusts (ET1 and ET3) and 
436 the formation of new faults around the tongue. These results suggest that the

437 basinward depocentre is more intensely deformed because: a) it formed earlier than

438

439

440

441

442

443

444

445

446

447

448

449

450

451

452

453

454

455

456

457

458

the landward depocentre and b) its local stresses were higher in response to the basinward thrust-advance of salt.

The front-thrusts FT 1-2 and pop-up fault systems PP 1-3 developed similarly to Model 1. A new pop-up, PP 4, nucleated above the backward thrust BT1 in the updip side of the system during Phase V (Fig. 5c). Syn-kinematic sedimentation reduced rotation of the front-thrust blocks (FT 1-2) on the basinward flank of the diapir, so they rotate less than those observed in Model 1 (Fig. 5b-c). No peripheral thrust system is developed in this model, which can be explained by the presence of a stronger depocentre at the basinward flank of the diapir buttressing downdip salt flow.

\subsubsection{Model 3: Influence of Early Sedimentation}

In Model 3, 1000m of sediment is deposited during Phases II to V and the evolution of the system is notably different because sedimentation starts before major inflation of the diapir and roof uplift occurred. Evolution during Phase I is identical to previous models (Fig. 4a), with initial squeezing of the stock, salt upwelling and minor arching of the roof and development of salt anticlines. In Phase II (Fig. 6a), a wide depocentre is formed on the basinward side of the diapir partially burying its basinward edge while the diapir continues to be squeezed and arch its roof. Pop-up structures form preferentially in the landward flank, presumably because of its thinner and weaker cover while smaller thrusts form in the opposite flank (Fig. 6a). The pop-up sets (PP1-2) formed during Phase II in Models 1 and 2 with less 
sediment input are supressed in this model due to the greater sediment load on the basinward flank.

\section{$461 \quad$ Figure 6 here}

462 During Phase III (Fig. 6b), the roof is uplifted and arched further than previous

463 models (Figs. 4c and 5a) with symmetric outward rotation around a central hinge generating earlier normal faulting at the hinge and smaller roof-edge thrusts (ET 1 and ET2) in comparison to Models 1 and 2. The syn-kinematic interval gets folded around the diapir and above topographic highs associated with uplifted fault blocks producing thinning and onlapping of sediments (Fig. 6b). In Phase IV (Fig. 6c), the roof is completely dismembered as more salt is expelled from the centre of the diapir and forcefully pierces the overburden, an evolution pattern characteristic of active diapirism driven by regional shortening (Vendeville and Jackson, 1992, Schultz-Ela et al., 1993 and Hudec and Jackson, 2007). After Phase $V$ the diapir breaks through its roof, further rotating and shouldering aside its flaps. The basinward side is disrupted by a major basinward roof-edge thrust (ET3) which makes its lower block rotate and become overturned (Fig. 6d).

The final diapir geometry varies dramatically relative to Models I and II, being considerably more symmetric, taller and thinner. Its feeder is almost completely pinched-out, having a minimum width of $120 \mathrm{~m}$, which represents $9.5 \%$ of its initial dimension and it would most likely be visualized on seismic datasets as a weld. Its final height is $3 \mathrm{~km}$, equivalent to $240 \%$ of its original height, and its overhangs have 480 virtually the same width (280 and $285 \mathrm{~m}$ on the basinward and landward margins) without forming any asymmetric tongue as in previous experiments. 
482 This geometry is characteristic of upright tear-drop diapirs (Hudec and Jackson, 2007) and is very distinctive compared with Models 1-2 in which asymmetric structures with a basinward-leaning salt tongue developed. In these models (Figs. 46), shortening is the main driver of diapirism and the amount of shortening is constant. Thus, the development of a much taller and symmetric squeezed diapir in Model 3 must be explained by the higher sediment input, which: i) generates a thicker basinward depocentre that buffers basinward salt flow to a point where it only moves upward and, ii) mildly increases differential loading, pumping more salt from the source-layer to the diapir forcing it to rise further. This is evidenced by a reduced thickness of the salt layer of $190 \mathrm{~m}$ (Fig. 6d, white tick on the source-layer).

In this model, faulting is dominated by front-thrusts (FT 2-4) in the updip edge of the system (FT 3-4, Fig. 5d). The large front-thrust FT1 associated with the source-fed salt advance and the pop-up set equivalent to PP2 in Models 1-2 (Figs. 4-5) do not develop in Model 3, whereas all other pop-up blocks (PP1, 3 and 4) are formed (Fig. $6 b)$. These differences are related to the higher sediment input and consequent burial of the diapir's basinward flank in Model 3 (Fig. 6), which causes strain in the overburden to be preferentially accommodated on the landward side where sedimentation is less intense. No roof-thrust (RT1) is formed and salt upwelling is accommodated mainly by roof-edge thrusts (ET1-3). ET3 is much larger in Model 3 and generates considerable displacement and folding of the syn-kinematic interval (Fig. 6d).

To demonstrate complete welding of the diapir, this experiment was run for an additional phase (Phase VI, Fig. 6e) to higher strains (48\% of shortening) with 
basinward, overthrusting and decapitating the diapir at mid-level (Fig. 6e), resulting

507 in a basinward-vergent thrusted weld.

\subsection{Influence of Sedimentation Rate on Salt Mobilisation and Geometry}

In this set of experiments, the effects of variable sedimentation rates on the evolution

510 of active diapirs are evaluated. Model 3 is chosen as a reference model for comparison due to its longer and higher sediment input, which results in a significant influence of sedimentation on diapir evolution (Table 1). The rate of sedimentation was varied while keeping all other parameters (e.g. timing, duration, strain rate) identical to Model 3. In Models 4 and 5, the effects of a reduced $(0.1 \mathrm{~m} / \mathrm{ka}$ or $200 \mathrm{~m} /$ Phase $)$ and increased $(0.15 \mathrm{~m} / \mathrm{ka}$ or $300 \mathrm{~m} /$ Phase $)$ sedimentation rate on diapir evolution are tested.

\subsubsection{Model 4: Reduced Sedimentation Rate $(0.1 \mathrm{~m} / \mathrm{ka}$ or $200 \mathrm{~m} / \mathrm{phase})$}

Model 4 has no sedimentation in Phase I and a reduced sedimentation rate relative to Model 3 in Phases II-V (Fig. 7a). In this model, an asymmetric basinward-vergent diapir is formed by basinward thrust advance of salt at the top of the diapir. The lower sedimentation rate on Model 4 relative to Model 3 results in a weaker and thinner basinward overburden, which does not generate a downdip barrier capable of lateral salt flow. Thus, a small basinward-leaning overhang (540 m, Fig. 7a) is

524 formed.

\section{Figure 7 here}

526 The final diapir height is smaller $(2.15 \mathrm{~km}$, Fig 7a) compared to Model 3 (3km, Fig.

$5276 \mathrm{~d}$ ) and this can be explained by the fact that more salt moves laterally in Model 4 than in Model 3 and, secondarily, by less differential loading on the source-layer in 
529 Model 4, evidenced by a slightly thicker salt layer at the updip side. The higher sedimentary loading of Model 3 is balanced by a higher structural loading around the diapir in Model 4 (see stacked fault blocks on the updip side of Model 4, Fig. 7a) and by a considerable amount of salt being carried away along the large basinwardvergent front-thrust FT 1 (Fig. 7a). Thus, the difference in differential loading and average of source-layer thickness are only minor $(15 \mathrm{~m})$ between these two models (compare Fig. 6d and 7a) and shows that differential loading and salt expulsion from the source-layer acts only as a secondary control on the development of these

537 distinct diapir geometries.

The roof is only partially dismembered by the formation of a keystone graben at the hinge, and it rotates considerably less in Model 4 due to reduced salt upwelling and roof uplift (compare Fig. 6d and 7a). No roof-thrust (RT1) is formed, but roof-edge thrusts (ET 1-3) are generated similar to other models where a salt tongue developed but with a more intricate pattern in Model 4 (Fig. 7a). The basinward synkinematic interval is more deformed with strong overturning and shearing of the prekinematic flap immediately beneath the salt tongue (Fig. 7a). This overturning is more intense in Model 4 than Model 3 due to the asymmetric advance of salt (Fig. 7a). In Model 4, the thinner and weaker basinward depocentre allows the development of PP2 and FT1 with basinward thrust advance of salt (Fig. 7a) whereas in Model 3 these faults do not form (Fig. 6d).

In Model 5, aggradation occurs during phase II to $\mathrm{V}$ with an increased sedimentation rate relative to Models 3 and 4 . Even though shortening is active and deforming the system throughout the experiment, the faster aggradation rate outpaces the salt rise 
553 rate and progressively buries the structure, impeding overall salt movement and

554 overburden deformation. Therefore, the changes observed compared with the 555 original diapir geometry are relatively minor (Fig. $7 b$ ).

556 The diapir is still squeezed and salt is pushed upward arching its roof but it is not

557 able to completely pierce and dismember the pre-shortening flaps. Both basinward and landward roof-edge thrusts (ET1 and ET2) develop without any intra-roof thrust (RT1). The resultant structure is a squeezed upright diapir with very little asymmetry between its overhangs and a final height of $1.8 \mathrm{~km}$, only $550 \mathrm{~m}$ higher than its original size, with a feeder width of $480 \mathrm{~m}$ (Fig. 7b). Fewer and smaller faults form in this model, especially in its basinward flank where sedimentation is more intense. Still, PP3 and a larger and asymmetric pop-up (PP4) develop in the landward flank (Fig. 7b).

\subsection{Summary and Comparison of Diapir Geometries}

566 Table 1 summarizes the variations of sedimentation patterns for each model and 567 final dimensions of their salt structures. In the first set of models (Models 1-3), an increase in diapir height is directly proportional to the amount of sediment and differential loading around the diapir, whereas asymmetry and horizontal salt advance are inversely proportional to the amount and duration of aggradation. There

571 is no relationship evident between stock width and sedimentation for these experiments.

573 For the second set of experiments (Models 3-5), an increase in aggradation rate is 574 inversely proportional to the amount of horizontal salt advance and asymmetry of the 575 diapir. Nevertheless, vertical salt movement is higher for the model with intermediate sedimentation rate and volume (Model 3), in which loading kept pace with diapir rise 
577

578

579

580

581

582

583

584

585

586

587

588

589

590

591

592

593

594

595

596

597

598

599

and suppressed lateral expansion of the diapir, similar to data shown by Weijermars et al. (2015). However, in the model with the slowest sedimentation rate (Model 4), salt was allowed to expand basinward, which, combined with a slightly smaller differential loading, induced less upward salt flow. In Model 5, the aggradation rate was faster than salt rise driven by shortening resulting in less diapirism and overburden deformation than previous models.

Despite the existence of a topographic slope in our models, active diapirism resulted in a relatively symmetric structure in Model 3. Conversely, in models of passive diapirism on a slope, diapirs invariably develop an asymmetric shape due to gravity flow downdip (Weijermars et al., 2015). This difference is due to the fact that in our examples, gravity flow on a basinward-dipping surface is skewed by shortening and higher sedimentary loading on the downdip side of the diapir where there is higher accommodation space due to the dip of the margin. This higher loading in Model 3 hinders basinward salt flow and allows the structure to grow taller than in any other models.

\subsection{Intra-Diapir Salt Flow}

Four marker-elements (A-D from top to bottom) were located at the centre of the stock for each model to analyse flow within the diapir (Fig. 8). Two marker-elements (elements $\mathrm{E}$ and $\mathrm{F}$ ) were also situated on the basal-salt layer on each flank of the diapir to investigate salt flow within the source-layer and into the diapir (Fig. 9). The trajectories of all elements are identical until the beginning of sedimentation for all models (Figs. 8-9).

\section{Figure 8 here}


601 Elements $A$ and $B$ from the uppermost and mid-upper central parts of the stock 602 respectively present a similar trend (Fig. 8b-c) with increase in vertical displacement and decrease of horizontal displacement as sedimentation thickness increases. Thus, in Model 1, the elements move farther basinward (1.45 km and $1.2 \mathrm{~km})$ and less upward $(1 \mathrm{~km})$ relative to Model 3, in which they rise further $(1.5 \mathrm{~km})$ with lesser basinward translation $(0.5 \mathrm{~km})$. For each model, the proportion of horizontal and vertical motion is broadly equal (slope of the curve $\sim 459$ until sedimentation begins and movement becomes predominantly vertical (blue and green curves, fig 8a).

609 Element C (Fig. 8d) represents flow in the lower-mid portion of the stock and shows

a decrease in both horizontal and vertical movement and increase in complexity of movement as sedimentation becomes more intense. In Model 3, with increased sedimentation, element C moves only $0.75 \mathrm{~km}$ upward and $0.6 \mathrm{~km}$ basinward; whereas in Model 1 it moves $1.1 \mathrm{~km}$ in both axes (Fig. 8d). Element D at the lower portion of the stock shows an even more erratic flow pattern later in its history (Fig. $8 e)$. This is associated with the thinning of the stock and to the increasing pressure of sediments on the remaining salt pedestal at the landward flank (Fig. 8a) pushing salt downward and inward towards the pedestal and the source-layer, as observed and predicted from the latest physical models (Dooley et al., 2009). This inward movement component is stronger in Model 3 where sedimentary loading is higher, pushing salt further into the pedestal. In these lower parts of the stock, the trajectories become more unstable as the feeder is significantly thinned $(61.6 \%$ in Model 2 to $90.4 \%$ in Model 3, Fig. 8a) and, consequently, interaction with the sides of the diapir impose additional stresses that interfere with salt movement and generate a complex flow pattern (Fig. 8 d-e). This instability is higher in Model 3 
where narrowing of the diapir is more intense and results in its almost complete pinch-out (Fig. 8a, d-e).

\subsubsection{Intra-Salt Flow for Models 3-5}

The amount of movement for all markers in Model 5 (with the highest sedimentation rate and volume) is considerably smaller than in Models 3 and 4 as the structure is rapidly buried and overall salt movement is impeded (Fig. 8f-i). The two uppermost elements (A and B, Fig. 8f-g) show higher basinward movement for Model 4 (lower sedimentation rate) and higher vertical movement for Model 3 (intermediate sedimentation rate). Vertical movement is favoured in Model 3 as the thicker basinward depocentre prevents horizontal spreading and the higher sedimentation rate relative to Model 4 generates more loading of the source-layer, expelling more salt towards the diapir (Fig 8a).

The mid-lower marker (Element C, Fig. 8h) shows a similar pattern to the previous set of experiments with a higher amount of vertical and basinward motion for Model 4, in which sedimentation rate and thickness are lower and the diapir is wider than in Model 3, resulting in less interference from the diapir walls. In the case of Model 5 where the structure gets rapidly buried in phase II, motion at this part of the stock is minor with a late component of inward flow as the diapir becomes less capable of pushing its progressively thicker roof.

The lower marker (Element D, Fig. 8i) shows an oscillatory flow pattern due to thinning of the stock and interactions with the side-walls, and a strong component of inward flow for all experiments. This inward flow is caused, firstly, by thinning of the feeder, which reduces salt motion from the lower portions towards the top of the diapir, and, secondly, by the pressure of the overriding landward block onto the 
649 remaining salt pushing elements back into the pedestal and source-layer (Fig. 8a).

650 Thus, inward flow is higher for Model 4, where the feeder is almost completely

651 pinched-out and salt in the lower portions of the diapir can no longer ascend 652 effectively.

\section{Figure 9 here}

$654 \quad$ 3.3.3. Source-Layer Markers

655 For the first set of models (Models 1-3), Element E shows a significant variation from 656 early basinward movement to late landward flow towards the diapir (Fig. 9a). The 657 amount of updip flow is directly proportional to sediment input where in Model 3

658

659

660

661

662

663

664

665

666

667

668

669

670 movement is focussed towards the diapir as sediment input was greater and started earlier (Fig. 9a). Despite the lack of sedimentation in Model 1, structural loading due to the propagation and imbrication of thrust blocks in the last two phases (Figs. 4d-e) results in additional differential loading of the source-layer in this area, pushing salt towards the diapir. Models 1 and 2 have identical early phases showing $106 \mathrm{~m}$ of basinward motion followed by 60 and $67 \mathrm{~m}$ of landward flow, respectively. In Model 3, only $10 \mathrm{~m}$ of early basinward flow occurs during the first phase followed by $365 \mathrm{~m}$ of landward and $40 \mathrm{~m}$ of upward movements (Fig. 9a).

Element $\mathrm{F}$ for Models 1-3 demonstrates that an increase in sediment input and loading is inversely proportional to the amount of basinward flow (Fig. 9b). This is due to the fact that sedimentation is more intense on the basinward flank of the diapir generating a stronger sedimentary cover downdip that reduces flow from the source-layer on the landward side of the diapir. 
671 For the second set of experiments, movement of Element $E$ on the basinward flank

672 is predominantly landwards, i.e. towards the diapir (Fig. 9c). In Model 3, in which

673 differential loading is more effective and the diapir becomes taller, movement is 674 stronger, whereas in Model 4 where sedimentation rate is reduced, flow towards the 675 diapir is minor (110 m landward, Fig. 9c). Model 5 has a higher sedimentation rate 676 than Model 4 but because the diapir becomes progressively buried, salt pumping into 677 the diapir is arrested and landward flow is less than in Model 3 (300 m landward, Fig. $6789 \mathrm{c})$.

679 For Models 3-5, Element F demonstrates a similar relationship to the first set of 680 experiments, where basinward movement and sedimentation rate are inversely proportional (Fig. 9d). In Model 5, Element F doesn't conform to the observed trend from Model 3 and 4 because as the diapir is progressively buried, upwelling and inflation is hindered forcing salt to move mainly horizontally and downdip (Fig. 9d). In the last phase there is a minor component of inward flow updip due to greater burial of the structure (Figs. $7 b$ and $9 d$ ).

The early basinward flow of Element $\mathrm{E}$ reflects downdip movement due to gravity and shear forces within the system and it can be regarded as a dominant Couette type of flow (Weijermars et al., 1993; Rowan et al., 2004) in stages prior to major differential loading acting on the source-layer. Later updip salt movement towards the diapir is diagnostic of a dominant Pouiseuille-type of flow (Weijermars et al., 1993; Rowan et al., 2004) in response to the increasing differential pressure of the overburden on the salt layer.

\section{4. Discussion}

\subsection{Applicability of DEM}


695

696

697

698

699

700

701

702

703

704

705

706

707

708

709

The experiments show that buried diapirs rejuvenated by regional shortening result in lateral squeezing and forceful piercement of salt, confirming previous studies using sand-box experiments (Vendeville and Jackson, 1992; Schultz-Ela et al., 1993; Rowan and Vendeville, 2006; Dooley et al., 2009; Dooley et al., 2015) and FEM (Schultz-Ela et al., 1993). Unless overwhelmed by extreme sedimentation rates, the diapir initially inflates and arches its roof, progressively rotating it outward until it becomes completely dismembered and shouldered aside in more advanced stages, in common with previous models (Vendeville and Jackson, 1992; Schultz-Ela et al., 1993; Dooley et al., 2015). A general upward movement is favoured by the development of reverse faults at the roof and edges of the diapir. This geometric evolution is notably similar to previous models of active diapirism driven by shortening (Vendeville and Jackson, 1992; Schultz-Ela et al., 1993; Jackson et al., 1994; Hudec and Jackson, 2007; Dooley et al., 2009) and to natural examples observed in seismic data (Fig. 10, see also Davison et al., 2000; Jackson et al., 2008 Albertz et al., 2010, Tari and Jabour, 2013; Rowan et al., 2016).

In models of salt flow, which involve solid-state creep and negligible inertial forces (i.e. Reynolds number $<<1$ ), geometric congruence ensures kinematic and dynamic similarity; despite the fact that numerical parameters are not identical to the real world (Weijermars and Schmeling, 1986; Weijermars et al., 1993; Schultz-Ela et al., 1993). The experiments presented in this study accurately simulate the geometric and dynamic evolution of diapirs rejuvenated by shortening supporting the feasibility of this technique when analysing diapirism driven by regional stresses.

Nevertheless, we emphasize that DEM is not the ultimate solution for modelling salt tectonics. Since it is based in a discontinuous numerical method, DEM may not be able to fully represent the complete mechanical behaviour of salt and model salt 
720 deformation driven exclusively by buoyancy. However, the resemblance of our

721 models to real-world geometries (Figs. 10 and 11) and physical experiments (Figs.

722 1d and 11c) and FEM (Fig. 1c) suggest that DEM is a valuable modelling technique

723 to evaluate the sequential evolution of diapirs and test and analyse the interplay

724 between diapirism, regional stresses, overburden deformation and sedimentation

725 (Fig. 12). The advantage of the DEM technique in modelling salt tectonics is that it

726 combines positive aspects of FEM and of physical models, such as the easy

727 reproducibility and numerical control of the former and the natural and more realistic

728 aspect of rock-deformation and sedimentation of the latter. It generates quick

729 analytical and scaled models of the sequential evolution of salt structures and 730 depocentres, allowing tracking of individual elements through time and space.

731 Furthermore, DEM can be also applied for 3D studies, as physical models, to

732 produce time-slices and multi-directional cross-sections that can aid in the analysis

733 of the variation of salt-related structural styles along-strike.

734 Figure 10 here

$735 \quad$ Figure 11 here

736 4.2. Effects of Sedimentation on the Rejuvenation of Diapirs

737 The results confirm that during rejuvenation of buried diapirs by shortening in a slope

738 setting, sedimentation acts as the main control on the development of upright

739 squeezed diapirs or asymmetric salt tongues (Fig. 12). The figure is sketch

740 representation of model results summarizing differences in diapir geometries relative

741 exclusively to variations in sedimentation. All parameters apart from sedimentation

742 are constant for all models so Fig. 12 illustrates how varying the timing (Fig. 12a)

743 and rate of sedimentation (Fig. 12b) can result in distinct styles of active diapirism. 
744 Examples of similar structures found in worldwide salt basins are also listed for comparison to each model (Fig. 12).

\section{$746 \quad$ Figure 12 here}

747 In models with low sediment input controlled either by timing (Models 1 and 2, fig.

748 12a) or rate of sedimentation (Model 4, fig. 12b) salt flows not only upward but also basinward due to the absence of a strong basinward buttress. The resultant structures are asymmetric and characterized by an allochthonous tongue formed by basinward thrust advance of salt over a thin cover, similar to various seismic examples (Fig. 1a, 10a and 13), such as in the NW Africa continental margin (e.g. Tari and Jabour, 2013, Tari et al., 2017), Nova Scotia (e.g. see Albertz et al., 2010, Deptuck and Kendell, 2017), Gabon (e.g. Jackson et al., 2008), Gulf of Mexico (e.g. see Schuster, 1995; Rowan, 1995; Rowan and Vendeville, 2006; Rowan et al., 2016), North German (Hudec and Jackson, 2011) and even intra-salt tongues in the Santos Basin, Brazil (see Jackson et al., 2015; Dooley et al., 2015).

In experiments with larger sediment volumes (e.g. Model 3, Fig. 12b), the thicker and stronger overburden buffers horizontal spreading of salt, especially in the basinward direction where the overburden is thicker, resulting in symmetric and upright diapirs. In Model 3, the rate of sedimentation is not high enough to completely bury the diapir as in Model 5, so the final structure is a typical tear-drop diapir such as the ones found in the North Sea (Davison et al., 2000), the Moroccan margin (Tari and Jabour, 2013), Nova Scotia (Albertz et al., 2010), Angola (Fig. 1b, Duval et al., 1993) and many other salt basins (Fig. 10b, 11 and 13a). Additional shortening of Model 3 results in complete pinch-out of the feeder and development of a basinward-vergent 
weld by overthrusting of the landward block, similar to examples found in the Lower

768 Congo and Kwanza Basin (Fig. 11).

\section{$769 \quad$ Figure 13 here}

770 Basinward tilting of the margin is another factor that influences the evolution of

771 diapirs (Dooley et al., 2015; Weijermars et al., 2015). When pelagic aggradation is absent or mild (Models 1, 2 and 4), basinward tilting favours downdip translation of salt due to the elevation head gradient along the top of the diapir (Weijermars et al., 2014; Hudec and Jackson 2007). When aggradation starts earlier or is more severe, however, (Models 3 and 5); this tilting hinders downdip translation of salt because it allows the development of a thicker and stronger depocentre in the basinward flank of the diapir. This suggests that allochthonous sheetlike structures formed by thrust advance, such as small salt tongues, occur preferentially associated with periods of relative sediment starvation in deep-water areas. In our models, the diapir roof does not become as heavily fragmented as in other physical models without syn-kinematic sedimentation (Dooley et al., 2015) because sedimentation acts as a barrier for lateral expansion of the diapir and roof extension.

The geometries of our models are notably similar to seismic examples (Fig. 10a-b and 11) and physical analogues (Fig. 10c), where results show the development of the notable features from natural examples such as diapir geometry, squeezed subvertical feeders, overhangs, thicker basinward depocentres, roof uplift and dismembering (e.g. Figs. 10 and 11). In some natural examples, differential salt thickness and overburden uplift across the diapir are comparable to model results (Fig. 11) whereas in others these can contrast with our experiments (Fig. 10b). 
791

792

793

794

795

796

797

798

799

800

801

802

803

804

805

806

807

808

809

810

811

812

813

814

irregularities on early salt geometries and other variables that may act in these systems, such as basement topography and 3D variations in sediment input and salt flow; or could also be related to difficulty in successfully imaging deep autochthonous salt layers and strata below or at the flanks of diapirs (Fig. 1a).

These results contribute to understanding the diversity of salt-related structural styles on various continental margin salt basins. Typical along-strike variations from segments dominated by upright symmetric diapirs (Fig. 10b) to others characterized by asymmetric and basinward-leaning diapirs and tongues (Fig. 10a) can be related to lateral changes of sedimentation rates and input to deep-water systems along these margins. Areas that experience higher sediment input will preferentially develop more symmetric structures whereas those receiving reduced sedimentation will favour the generation of asymmetric diapirs and salt sheets (Fig. 12, e.g. Tari and Jabour, 2013; Albertz et al., 2010; Deptuck and Kendell, 2017).

Moreover, similar along-dip shifts in diapirism style from symmetric structures updip to asymmetric diapirs, tongues and sheets downdip are common in many margins (e.g. Tari and Jabour, 2013; Deptuck and Kendell, 2017; Tari et al., 2017; Lentini et al., 2010; Jackson and Hudec, 2017, see their figs. 10.71 and 10.73) with both syn(Fig. 13a) and post-rift salt (Fig. 13b) can also be partially associated with variations in sediment input and rates as these are usually higher updip than further downdip. This is not true everywhere, as salt tectonics is also affected by many other factors such as basement topography (Dooley et al., 2016), intra-salt variability (Cartwright et al., 2012; Jackson et al., 2015), out-of-plane salt flow (Demercian et al., 1993; Rowan et al., 1993) and initial diapir geometries (Dooley et al., 2015) where our models involve only diapirism driven by shortening. 
815

816

817

818

819

820

821

822

823

The Central Louisiana segment of the Gulf of Mexico salt basin is an example of a more complex scenario where asymmetric basinward-leaning structures, i.e. counter-regional systems (Schuster 1995), predominate near the shelf passing downdip to symmetric systems, i.e. salt-stocks, at the upper slope and further downdip to another asymmetric domain referred to as the Sigsbee canopy system (Diegel et al., 1995; Peel 1995; Rowan 1995; Hudec et al., 2013). This variation may be associated to differences in early diapir geometries, i.e. basinward-leaning diapirs due to early progradation (Diegel et al., 1995).

\subsection{Thrust-Advance of Allochthonous Salt}

The experiments confirm that allochthonous salt tongues can also develop without salt extrusion (Figs. 4, 5 and 12a). In scenarios where a previously buried salt stock is squeezed without a thick basinward buttress, salt is pushed up and basinward carrying a thin carapace of pre-kinematic sediments across a thick footwall, similar to models of thrust advance and the plug-fed-thrusts lineage of Hudec and Jackson (2006). As more salt is squeezed from the stock by progressive shortening and, secondarily, expelled from the source-layer by differential loading, it continues to rise and pierce the overburden above a basinward-vergent thrust, inflating the salt tongue while its thin roof is rotated and deformed, similar to physical model examples (Figs. 1-d and 10c, see also Dooley et al., 2015).

This type of generation of allochthonous salt sheets is expected to occur in areas where stresses are high enough to deform the diapir's roof (Hudec and Jackson, 2006), such as in the toe-of-slope and salt pinch-out in passive margin settings and in salt basins affected by thick-skinned shortening such as Morocco (Hafid et al., 2000; Hafid et al., 2006; Tari and Jabour, 2013), the North Sea (Davison et al., 2000) 
839 Central European basins (Graham et al., 2012; Ferrer et al., 2012), the Great Kavir

840 (Jackson et al., 1990; Talbot and Alftabi, 2004; Hudec and Jackson, 2011) and in the

841 Flinders Range in Australia (Rowan and Vendeville, 2006). In many cases, due to 842 difficulties in subsalt seismic imaging, limited vertical resolution and the highly 843 strained nature of sediments adjacent to salt structures, accurate identification of the mechanism responsible for the emplacement of allochthonous features can be problematic in seismic data. Thus forward modelling techniques such as the one used in this study can contribute to improving understanding of the processes and evolution of these structures.

\subsection{Deformational Styles within the Overburden}

The results shed light into deformational processes on the overburden related to active diapirism driven by shortening that are observed in seismic data (Fig. 11) and physical model examples (Fig. 1d and 10c) but not produced by FEM techniques. Even though diapirs localize most of the strain (Weijermars et al., 1993; Rowan and Vendeville, 2006), in both cases of symmetric upright diapirs and asymmetric diapirs with salt tongues formed by shortening, roof-thrusts and roof-edge thrusts develop as the roof gets dismembered and rotated outward over adjacent depocentres (Fig. 12), similar to results presented in Schultz-Ela (1993), Nilsen and Vendeville (1995) and Dooley et al. (2009, 2015). Active piercement and inflation of a buried salt tongue is also accommodated by imbricate thrust systems immediately basinward of the edge of the advancing sheet (Figs. 5 and 10c) similar to physical models (Dooley et al., 2009; Hudec and Jackson, 2011).

861 In nature, these faults can occur at or below the limit of seismic resolution or in highly strained or sub-salt areas, thus being usually visualized through core or well data 
863 (Davison et al., 2000), although in some circumstances they can be large enough to

864 be resolved by seismic imaging as in the Banff Diapir in the Central Graben (Fig. 1b),

865

866

867

868

869

870

871

872

874

875

876

877

879

880

881

882

883

884

885

886

the Cegonha Diapir, offshore Angola (Duval et al., 1993) and at the Astrid fold-thrust belt offshore Gabon (Jackson and Hudec, 2008). The recognition of faults around salt structures is important as they can act as both conduit or seal for hydrocarbons depending on their depth and lithology.

\section{Conclusions}

DEM is a very efficient and inexpensive tool to analyse the structural and stratigraphic evolution of sedimentary basins. Although it has limitations in modelling certain scenarios of salt tectonics, i.e. purely buoyancy-driven deformation, this novel approach is a useful tool to guide seismic interpretation and to assess the interplay of salt tectonics and sedimentation due to: i) results are easily reproducible, ii) it allows analysis of the sequential evolution of the structures and tracking of individual elements in the system; and, especially because, iii) it produces more realistic and natural deformation of the overburden, as opposed to other numerical models, thus being capable of improving our current knowledge of deformation styles and sedimentation processes around diapirs.

Modelling results confirm that shortening of buried diapirs on a slope setting can generate two end-member salt geometries according to sedimentation patterns: i) asymmetric diapirs with basinward-vergent salt tongues and ii) upright squeezed diapirs. When the sedimentation rate is low or sedimentation starts late relative to rejuvenation of the diapir, salt movement is asymmetric resulting in basinwardvergent structures. When the sedimentation rate is higher or occurs earlier, resultant structures are symmetric and defined as upright squeezed or tear-drop diapirs. 
887 Although diapirs with strong asymmetry occur in most of our models (Fig. 12, Models

8881,2 and 4) due to the basinward dip of the margin and the position of the diapir slightly closer to the updip moving wall, early and intense sedimentation can counteract this effect and generate relatively symmetric and upright structures (Fig. 12, 891 Models 3 and 5).

The key structures in our results are comparable to salt and respective overburden geometries of many diapirs around the world showing the applicability of DEM to reproduce accurately the geometric and dynamic behaviour of salt deformation driven by regional stresses.

The models presented in this paper contribute to the understanding of variations in salt-related structural styles along continental margins due to lateral changes of sedimentation rates and input to deep-water systems. They also explain downdip variations of structural styles observed in passive margins salt basins, where more symmetric structures prevail in the updip domains due to higher sediment input and sedimentation rates whereas asymmetric diapirs and tongues develop further downdip where sedimentation is less intense.

\section{Acknowledgements}

We wish to thank Rob Gawthorpe, Neil Mitchell, Andrew Newton and Giovanni Berttoti for sharing their insights and criticism. We also thank Gabor Tari and Tim Dooley for reviewing this paper and providing constructive criticism which helped improving this paper. We thank ONHYM and Chevron for allowing us to use their data from Morocco. The main author would also like to thank the Science without Borders program and CNPQ, Brazil for sponsoring his PhD research. Schlumberger is acknowledged for provision of Petrel software to the University of Manchester. 


\section{References}

912 Abe, S., Urai, J. L., 2012. Discrete element modeling of boudinage: Insights on rock

913 rheology, matrix flow, and evolution of geometry. Journal of Geophysical Research:

914 Solid Earth, 117(B1).

915 Adam, J., Krezsek, C., 2012. Basin-scale salt tectonic processes of the Laurentian

916 Basin, Eastern Canada: insights from integrated regional 2D seismic interpretation

917 and 4D physical experiments. Geological Society, London, Special

918 Publications, 363(1), 331-360.

919 Albertz, M., Beaumont, C., Shimeld, J. W., Ings, S. J., Gradmann, S., 2010. An 920 investigation of salt tectonic structural styles in the Scotian Basin, offshore Atlantic

921 Canada: 1. Comparison of observations with geometrically simple numerical 922 models. Tectonics, 29(4).

923 Albertz, M., Ings, S. J., 2012. Some consequences of mechanical stratification in 924 basin-scale numerical models of passive-margin salt tectonics. Geological Society, 925 London, Special Publications, 363(1), 303-330.

926 Allen, M. P., Tildesley, D. J., 1987. Molecular Simulation of Liquids. Clarendon, 927 Oxford.

928 Botter, C., Cardozo, N., Hardy, S., Lecomte, I., \& Escalona, A., 2014. From 929 mechanical modeling to seismic imaging of faults: A synthetic workflow to study the 930 impact of faults on seismic. Marine and Petroleum Geology, 57, 187-207.

931 Birch, P., Haynes, J., 2003. The Pierce Field, Blocks 23/22a, 23/27, UK North 932 Sea. Geological Society, London, Memoirs, 20(1), 647-659. 
933 Brun, J. P., Fort, X., 2011. Salt tectonics at passive margins: Geology versus

934 models. Marine and Petroleum Geology, 28(6), 1123-1145.

935 Cartwright, J., Jackson, M., Dooley, T., Higgins, S., 2012. Strain partitioning in 936 gravity-driven shortening of a thick, multilayered evaporite sequence. Geological 937 Society, London, Special Publications, 363(1), 449-470.

938 Cramez, C., Jackson, M. P. A., 2000. Superposed deformation straddling the 939 continental-oceanic transition in deep-water Angola. Marine and Petroleum Geology, 17(10), 1095-1109.

Davison, I., Alsop, G. I., Evans, N. G., Safaricz, M., 2000. Overburden deformation patterns and mechanisms of salt diapir penetration in the Central Graben, North Sea. Marine and Petroleum Geology, 17(5), 601-618.

Davison, I., Alsop, I., Birch, P., Elders, C., Evans, N., Nicholson, H., Young, M., 2000. Geometry and late-stage structural evolution of Central Graben salt diapirs, North Sea. Marine and Petroleum Geology, 17(4), 499-522.

Davison, I., 2005. Central Atlantic margin basins of North West Africa: geology and hydrocarbon potential (Morocco to Guinea). Journal of African Earth Sciences, 43(1), 254-274.

Davison, I., Anderson, L., Nuttall, P., 2012. Salt deposition, loading and gravity 951 drainage in the Campos and Santos salt basins. Geological Society, London, Special 952 Publications, 363(1), 159-174.

953 Demercian, S., Szatmari, P., \& Cobbold, P. R., 1993. Style and pattern of salt diapirs 954 due to thin-skinned gravitational gliding, Campos and Santos basins, offshore Brazil. 955 Tectonophysics, 228(3-4), 393-433. 
956 Deptuck, M. E., Kendell, K. L., 2017. A review of Mesozoic-Cenozoic Salt Tectonics

957 Along the Scotian Margin, Eastern Canada. In: Soto, J. I., Flinch, J., \& Tari, G. 958 (Eds.). (2017). Permo-Triassic Salt Provinces of Europe, North Africa and the 959 Atlantic Margins: Tectonics and Hydrocarbon Potential. Elsevier, 287-312.

960 Diegel, F. A., Karlo, J. F., Schuster, D. C., Shoup, R. C., \& Tauvers, P. R., 1995.

961 Cenozoic structural evolution and tectono-stratigraphic framework of the northern 962 Gulf Coast continental margin.

963 Donzé, F., Mora, P., Magnier, S. A., 1994. Numerical simulation of faults and shear 964 zones. Geophysical Journal International, 116(1), 46-52.

965 Dooley, T. P., Jackson, M., \& Hudec, M. R., 2007. Initiation and growth of salt-based 966 thrust belts on passive margins: results from physical models. Basin Research, 967 19(1), 165-177.

968 Dooley, T. P., Jackson, M. P., Hudec, M. R., 2009. Inflation and deflation of deeply 969 buried salt stocks during lateral shortening. Journal of Structural Geology, 31(6), $970 \quad 582-600$.

971 Dooley, T. P., Hudec, M. R., Jackson, M. P., 2012. The structure and evolution of 972 sutures in allochthonous salt. AAPG bulletin, 96(6), 1045-1070.

973 Dooley, T. P., Jackson, M. P. A., \& Hudec, M. R., 2015. Breakout of squeezed 974 stocks: dispersal of roof fragments, source of extrusive salt and interaction with 975 regional thrust faults. Basin Research, 27(1), 3-25.

976 Dooley, T. P., Hudec, M. R., Carruthers, D., Jackson, M. P., \& Luo, G., 2016. The 977 effects of base-salt relief on salt flow and suprasalt deformation patterns-Part 1 : 978 Flow across simple steps in the base of salt. Interpretation, 5(1), SD1-SD23. 
979 Dooley, T. P., Jackson, M. P., Jackson, C. A. L., Hudec, M. R., Rodriguez, C. R.,

980

981

982

983

984

985

986

987

988

989

990

991

992

993

994

995

996

997

998

999

1000

2015. Enigmatic structures within salt walls of the Santos Basin-Part 2: Mechanical explanation from physical modelling. Journal of Structural Geology, 75, 163-187.

Duval, B., Cramez. C., Schultz-Ela. D. D., Jackson, M. P. A., 1993. Extension, reactive diapirism, salt welding and contraction at Cegonha, Kwanza Basin, Angola (extended abs.) in American Association of Petroleum Geologists International Hedberg Research Conference, Abstract Volume, Bath, England, p. 41-43.

Ferrer, O., Jackson, M. P. A., Roca, E., Rubinat, M., 2012. Evolution of salt structures during extension and inversion of the Offshore Parentis Basin (Eastern Bay of Biscay). Geological Society, London, Special Publications, 363(1), 361-380.

Fiduk, J. C., Rowan, M. G., 2012. Analysis of folding and deformation within layered evaporites in Blocks BM-S-8 and-9, Santos Basin, Brazil. Geological Society, London, Special Publications, 363(1), 471-487.

Finch, E., Hardy, S., Gawthorpe, R., 2003. Discrete element modelling of contractional fault-propagation folding above rigid basement fault blocks. Journal of Structural Geology, 25(4), 515-528.

Finch, E., Hardy, S., Gawthorpe, R., 2004. Discrete-element modelling of extensional fault-propagation folding above rigid basement fault blocks. Basin research, 16(4), 467-488.

Fletcher, R. C., Hudec, M. R., Watson, I. A., 1995. Salt glacier and composite sediment-salt glacier models for the emplacement and early burial of allochthonous salt sheets. 
1001 Fort, X., Brun, J. P., Chauvel, F., 2004. Salt tectonics on the Angolan margin, 1002 synsedimentary deformation processes. AAPG bulletin, 88(11), 1523-1544.

1003 Fullsack, P., 1995. An arbitrary Lagrangian-Eulerian formulation for creeping flows 1004 and its application in tectonic models. Geophysical Journal International, 120(1), 11005 23.

1006 Gaullier, V., Mart, Y., Bellaiche, G., Mascle, J., Vendeville, B. C., Zitter, T., Party, S. 1007 L. P. I. S., 2000. Salt tectonics in and around the Nile deep-sea fan: insights from the 1008 1009 PRISMED II cruise. Geological Society, London, Special Publications, 174(1), 111129.

Ge, H., Jackson, M. P., Vendeville, B. C., 1997. Kinematics and dynamics of salt tectonics driven by progradation. AAPG bulletin, 81(3), 398-423.

1012 Gemmer, L., Ings, S. J., Medvedev, S., Beaumont, C., 2004. Salt tectonics driven by differential sediment loading: stability analysis and finite-element experiments. Basin 1014 Research, 16(2), 199-218.

Gemmer, L., Beaumont, C., Ings, S. J., 2005. Dynamic modelling of passive margin salt tectonics: effects of water loading, sediment properties and sedimentation patterns. Basin Research, 17(3), 383-402.

Gradmann, S., Beaumont, C., Albertz, M., 2009. Factors controlling the evolution of 1019 the Perdido Fold Belt, northwestern Gulf of Mexico, determined from numerical 1020 models. Tectonics, 28(2).

1021 Gradmann, S., Beaumont, C., 2016. Numerical modelling study of mechanisms of 1022 mid-basin salt canopy evolution and their potential applications to the Northwestern Gulf of Mexico. Basin Research. 
1024 Graham, R., Jackson, M., Pilcher, R., Kilsdonk, B., 2012. Allochthonous salt in the 1025 sub-Alpine fold-thrust belt of Haute Provence, France. Geological Society, London, 1026 Special Publications, 363(1), 595-615.

1027

Hafid, M., 2000. Triassic-early Liassic extensional systems and their Tertiary 1028 inversion, Essaouira Basin (Morocco). Marine and Petroleum Geology, 17(3), 4091029 429.

Hafid, M., Zizi, M., Bally, A. W., Salem, A. A., 2006. Structural styles of the western onshore and offshore termination of the High Atlas, Morocco.Comptes Rendus 1032 Geoscience, 338(1), 50-64.

Harding, R., Huuse, M., 2015. Salt on the move: Multi stage evolution of salt diapirs 1034 in the Netherlands North Sea. Marine and Petroleum Geology, 61, 39-55.

1035 Hardy, S., Finch, E., 2005. Discrete-element modelling of detachment folding. Basin 1036 Research, 17(4), 507-520.

1037 Hardy, S., Finch, E., 2006. Discrete element modelling of the influence of cover 1038 strength on basement-involved fault-propagation folding.Tectonophysics, 415(1), 225-238.

Hardy, S., Finch, E., 2007. Mechanical stratigraphy and the transition from trishear to kink-band fault-propagation fold forms above blind basement thrust faults: a discrete1042 element study. Marine and Petroleum Geology, 24(2), 75-90.

Hudec, M. R., Jackson, M. P., 2004. Regional restoration across the Kwanza Basin, 1044 Angola: Salt tectonics triggered by repeated uplift of a metastable passive 1045 margin. AAPG bulletin, 88(7), 971-990. 
Hudec, M. R., Jackson, M. P., 2006. Advance of allochthonous salt sheets in passive

1047 margins and orogens. AAPG bulletin, 90(10), 1535-1564.

1048 Hudec, M. R., Jackson, M. P., 2007. Terra infirma: Understanding salt 1049 tectonics. Earth-Science Reviews, 82(1), 1-28.

1050 Hudec, M. R., Jackson, M. P., 2009. Interaction between spreading salt canopies 1051 and their peripheral thrust systems. Journal of Structural Geology, 31(10), 111410521129.

1053 Hudec, M. R., Jackson, M. P., Vendeville, B. C., Schultz-Ela, D. D., Dooley, T. P. 1054 2011. The salt mine: A digital atlas of salt tectonics.

1055 Hudec, M. R., Norton, I. O., Jackson, M. P., Peel, F. J., 2013. Jurassic evolution of 1056 the Gulf of Mexico salt basin. AAPG bulletin, 97(10), 1683-1710.

1057 Jackson, M. P. A., Cornelius, R. R., Craig, C. H., Gansser, A., Stöcklin, J., and 1058 Talbot, C. J., 1990. Salt diapirs of the Great Kavir, central Iran. Geological Society of 1059 America Memoirs, 177, 1-150.

1060 Jackson, M. P., Vendeville, B. C., and Schultz-Ela, D. D., 1994. Structural dynamics 1061 of salt systems. Annual Review of Earth and Planetary Sciences, 22, 93-117.

1062 Jackson, M. P., Hudec, M. R., Jennette, D. C., Kilby, R. E., 2008. Evolution of the 1063 Cretaceous Astrid thrust belt in the ultradeep-water Lower Congo Basin, Gabon. 1064 AAPG bulletin, 92(4), 487-511.

1065 Jackson, M. P., \& Hudec, M. R., 2017. Salt Tectonics: Principles and Practice. 1066 Cambridge University Press. 
1067 Jackson, C. A. L., Jackson, M. P., Hudec, M. R., Rodriguez, C. R., 2015. Enigmatic 1068 structures within salt walls of the Santos Basin-Part 1: Geometry and kinematics 1069 from 3D seismic reflection and well data. Journal of Structural Geology, 75, 135-162.

1070 Jackson, C. A. L., Jackson, M. P., Hudec, M. R., 2015. Understanding the kinematics 1071 of salt-bearing passive margins: A critical test of competing hypotheses for the origin 1072 of the Albian Gap, Santos Basin, offshore Brazil. Geological Society of America 1073 Bulletin, 127(11-12), 1730-1751.

1074 Jackson, C. A. L., Lewis, M. M., 2016. Structural style and evolution of a salt1075 influenced rift basin margin; the impact of variations in salt composition and the role 1076 of polyphase extension. Basin Research, 28(1), 81-102.

1077 Johnson, R. B., \& DeGraff, J. V., 1988. Principles of engineering geology. Wiley.

1078 Kupfer, D. H. (1968). Relationship of internal to external structure of salt domes.

1079 Lentini, M. R., Fraser, S. I., Sumner, H. S., \& Davies, R. J. (2010). Geodynamics of 1080 the central South Atlantic conjugate margins: implications for hydrocarbon potential. 1081 Petroleum Geoscience, 16(3), 217-229.

1082

Li, S. Y., Urai, J. L., 2016. Rheology of rock salt for salt tectonics modeling. 1083 Petroleum Science, 13(4), 712-724.

1084 Liang, W. G., Yang, C. H., Zhao, Y. S., Dusseault, M. B., \& Liu, J., 2007. 1085 Experimental investigation of mechanical properties of bedded salt rock. 1086 International Journal of Rock Mechanics and Mining Sciences, 44(3), 400-411. 
1087

1088

1089

1090

1091

1092

1093

1094

1095

1096

1097

1098

1099

1100

1101

1102

1103

1104

1105

1106

1107

1108

Matias, H., Kress, P., Terrinha, P., Mohriak, W., Menezes, P.T., Matias, L., Santos,

F. Sandnes, F., 2011. Salt tectonics in the western Gulf of Cadiz, southwest Iberia. AAPG bulletin, 95(10), 1667-1698.

McGuinness, D. B., Hossack, J. R., 1993. The development of allochthonous salt sheets as controlled by the rates of extension, sedimentation, and salt supply. In Rates of geological processes: Gulf Coast Section SEPM 14th Annual Research Conference (pp. 127-139).

Mohriak, W.U., Macedo, J.M., Castellani, R.T., Rangel, H.D., Barros, A.Z.N., Latgé, M.A.L., Mizusaki, A.M.P., Szatmari, P., Demercian, L.S., Rizzo, J.G. Aires, J.R., 1995. Salt tectonics and structural styles in the deep-water province of the Cabo Frio region, Rio de Janeiro, Brazil.

Mohriak, W. U., Szatmari, P., Anjos, S., 2012. Salt: geology and tectonics of selected Brazilian basins in their global context. Geological Society, London, Special Publications, 363(1), 131-158.

Montgomery, S. L., Moore, D., 1997. Subsalt play, Gulf of Mexico: a review: AAPG Bulletin, v. 81, p. 871-896.

Mora, P., Place, D., 1993. A lattice solid model for the nonlinear dynamics of earthquakes. International Journal of Modern Physics C, 4(06), 1059-1074.

Mora, P., Place, D., 1994. Simulation of the frictional stick-slip instability.Pure and applied geophysics, 143(1-3), 61-87.

Nelson, T. H., Fairchild, L., 1989. Emplacement and evolution of salt sills in the northern Gulf of Mexico. 
Nilsen, K. T., Vendeville, B. C., Johansen, J.T., 1995 Influence of regional tectonics

1110

1111

1112

on halokinesis in the Nordkapp Basin, Barents Sea, in M. P. A. Jackson, D. G.

Roberts, and S. Snelson, eds., Salt tectonics: a global perspective: AAPG Memoir 65 , p. 413-436.

Place, D., Lombard, F., Mora, P., Abe, S., 2002. Simulation of the micro-physics of rocks using LSMearth. In Earthquake Processes: Physical Modelling, Numerical Simulation and Data Analysis Part I (pp. 1911-1932). Birkhäuser Basel.

Quirk, D. G., Schødt, N., Lassen, B., Ings, S. J., Hsu, D., Hirsch, K. K., Von Nicolai, C., 2012. Salt tectonics on passive margins: examples from Santos, Campos and Kwanza basins. Geological Society, London, Special Publications, 363(1), 207-244.

Rowan, M. G., 1993. A systematic technique for the sequential restoration of salt structures. Tectonophysics, 228(3-4), 331-348.

Rowan, M. G., 1995. Structural styles and evolution of allochthonous salt, central Louisiana outer shelf and upper slope, in M. P. A. Jackson, D. G. Roberts, and S. Snelson, eds., Salt tectonics: a global perspective: AAPG Memoir 65, p. 199-228.

Rowan, M. G., Trudgill, B. D., Carl Fiduk, J., 2000. Deep-Water, Salt-Cored Foldbelts: Lessons from the Mississippi Fan and Perdido Foldbelts, Northern Gulf of Mexico. Atlantic rifts and continental margins, 173-191.

Rowan, M. G., Peel, F. J., Vendeville, B. C., 2004. Gravity-driven fold belts on passive margins. In: McKlay, K.R. (Ed.) Thrust tectonics and Hydrocarbon Systems. AAPG Memoir 82, 157-182. 
1130 Rowan, M. G., Vendeville, B. C., 2006. Foldbelts with early salt withdrawal and

1131

1132

1133

1134

1135

1136

1137

1138

1139

1140

1141

1142

1143

1144

1145

1146

1147

1148

1149

1150 Talbot, C. J., 1993. Spreading of salt structures in the Gulf of 1151 Mexico. Tectonophysics, 228(3-4), 151-166. 
1152 Talbot, C., Aftabi, P., 2004. Geology and models of salt extrusion at Qum Kuh, 1153 central Iran. Journal of the Geological Society 161(2), 321-334.

1154 Tari, G., Molnar, J., Ashton, P., Hedley, R., 2000. Salt tectonics in the Atlantic margin 1155 of Morocco. The Leading Edge, 19(10), 1074-1078.

1156 Tari, G., Molnar, J., Ashton, P., 2003. Examples of salt tectonics from West Africa: a 1157 comparative approach. Geological Society, London, Special Publications, 207(1), 851158104.

1159 Tari, G., Jabour, H., 2013. Salt tectonics along the Atlantic margin of 1160 Morocco. Geological Society, London, Special Publications, 369(1), 337-353.

1161 Tari, G., Novotny, B., Jabour, H., Hafid, M., 2017. Salt tectonics along the Atlantic 1162 Margin of NW Africa (Morocco and Mauritania). In: Soto, J. I., Flinch, J., \& Tari, G. 1163 (Eds.). (2017). Permo-Triassic Salt Provinces of Europe, North Africa and the 1164 Atlantic Margins: Tectonics and Hydrocarbon Potential. Elsevier, 331-351.

1165 Tildesley, D. J., Allen, M. P., 1987. Computer simulation of liquids. Oxford Science 1166 Publications, Oxford.

1167 Trusheim, F., 1960. Mechanism of salt migration in northern Germany.AAPG 1168 Bulletin, 44(9), 1519-1540.

1169 Turcotte, D. L., Schubert, G., 2002. Geodynamics, Cambridge University Press, $1170 \quad 456 p$.

1171 Urai, J. L., Spiers, C. J., Zwart, H. J., Lister, G. S., 1986. Weakening of rock salt by 1172 water during long-term creep. Nature, 324(6097): 554-557. 
1173 Van Gent, H., Urai, J. L., De Keijzer, M., 2011. The internal geometry of salt 1174 structures-A first look using 3D seismic data from the Zechstein of the

1175 Netherlands. Journal of Structural Geology 33(3), 292-311.

1176 Vendeville, B. C., Jackson, M. P. A., 1992. The rise of diapirs during thin-skinned 1177 extension. Marine and Petroleum Geology, 9(4), 331-354.

1178 Vendeville, B. C., Ge, H., Jackson, M. P. A., 1995. Scale models of salt tectonics 1179 during basement-involved extension. Petroleum Geoscience, 1(2), 179-183.

1180 Vendeville, B. C. 2002. A new interpretation of Trusheim's classic model of salt-diapir 1181 growth. Gulf Coast Association of Geological Societies Transactions, 52, 943-952.

1182 Wagner, B. H., \& Jackson, M. P., 2011. Viscous flow during salt welding. 1183 Tectonophysics, 510(3), 309-326.

1184 Wang, Y. F., 1988. Salt tongues in northern Gulf of Mexico. AAPG Bulletin (United 1185 States), 72(CONF-880301).

1186 Weijermars, R., Schmeling, H., 1986. Scaling of Newtonian and non-Newtonian fluid 1187 dynamics without inertia for quantitative modelling of rock flow due to gravity 1188 (including the concept of rheological similarity). Physics of the Earth and Planetary 1189 Interiors, 43(4), 316-330.

1190 Weijermars, R., Jackson, M. T., Vendeville, B., 1993. Rheological and tectonic 1191 modeling of salt provinces. Tectonophysics, $217(1-2), 143-174$.

1192 Weijermars, R., Hudec, M. R., Dooley, T. P., \& Jackson, M. P. A., 2015. 1193 Downbuilding salt stocks and sheets quantified in 3-D analytical models. Journal of 1194 Geophysical Research: Solid Earth, 120(6), 4616-4644. 
1195 Whitman, J. M., Davies, T. A., 1979. Cenozoic oceanic sedimentation rates: How 1196 good are the data?. Marine Geology, 30(3-4), 269-284.

1197 Wu, S., Bally, A. W., Cramez, C., 1990. Allochthonous salt, structure and 1198 stratigraphy of the north-eastern Gulf of Mexico. Part II: Structure. Marine and 1199 Petroleum Geology, 7(4), 334-370.

1200 Zhu, H. P., Zhou, Z. Y., Yang, R. Y., \& Yu, A. B., 2008. Discrete particle simulation of 1201 particulate systems: a review of major applications and findings. Chemical 1202 Engineering Science, 63(23), 5728-5770. 


\section{ACCEPTED MANUSCRIPT}

\begin{tabular}{|c|c|c|c|c|c|c|c|}
\hline MODEL & $\begin{array}{c}\text { Thickness of syn-kinematic } \\
\text { sediments }(\mathrm{m})\end{array}$ & $\begin{array}{c}\text { Beggining of } \\
\text { aggradation }\end{array}$ & $\begin{array}{c}\text { Sedimentation } \\
\text { rate }(\mathrm{m} / \mathrm{ka})\end{array}$ & Height $(\mathrm{km})$ & Width $(\mathrm{m})$ & $\begin{array}{c}\text { Seaward } \\
\text { overhang }(\mathrm{m})\end{array}$ & $\begin{array}{c}\text { Landward } \\
\text { overhang }(\mathrm{m})\end{array}$ \\
\hline 1 & 0 & - & - & 2 & 280 & 750 & 300 \\
\hline 2 & 500 & Phase IV & 0.125 & 2.2 & 300 & 485 & 360 \\
\hline 3 & 1000 & Phase II & 0.125 & 3 & 120 & 280 & 285 \\
\hline 4 & 1000 & Phase II & 0.100 & 2.15 & 290 & 540 & 265 \\
\hline 5 & 1000 & Phase II & 0.150 & 1.8 & 480 & 130 & 110 \\
\hline
\end{tabular}

Table 1: Summary of initial parameters and final response of each model presented. 


\section{ACCEPTED MANUSCRIPT}
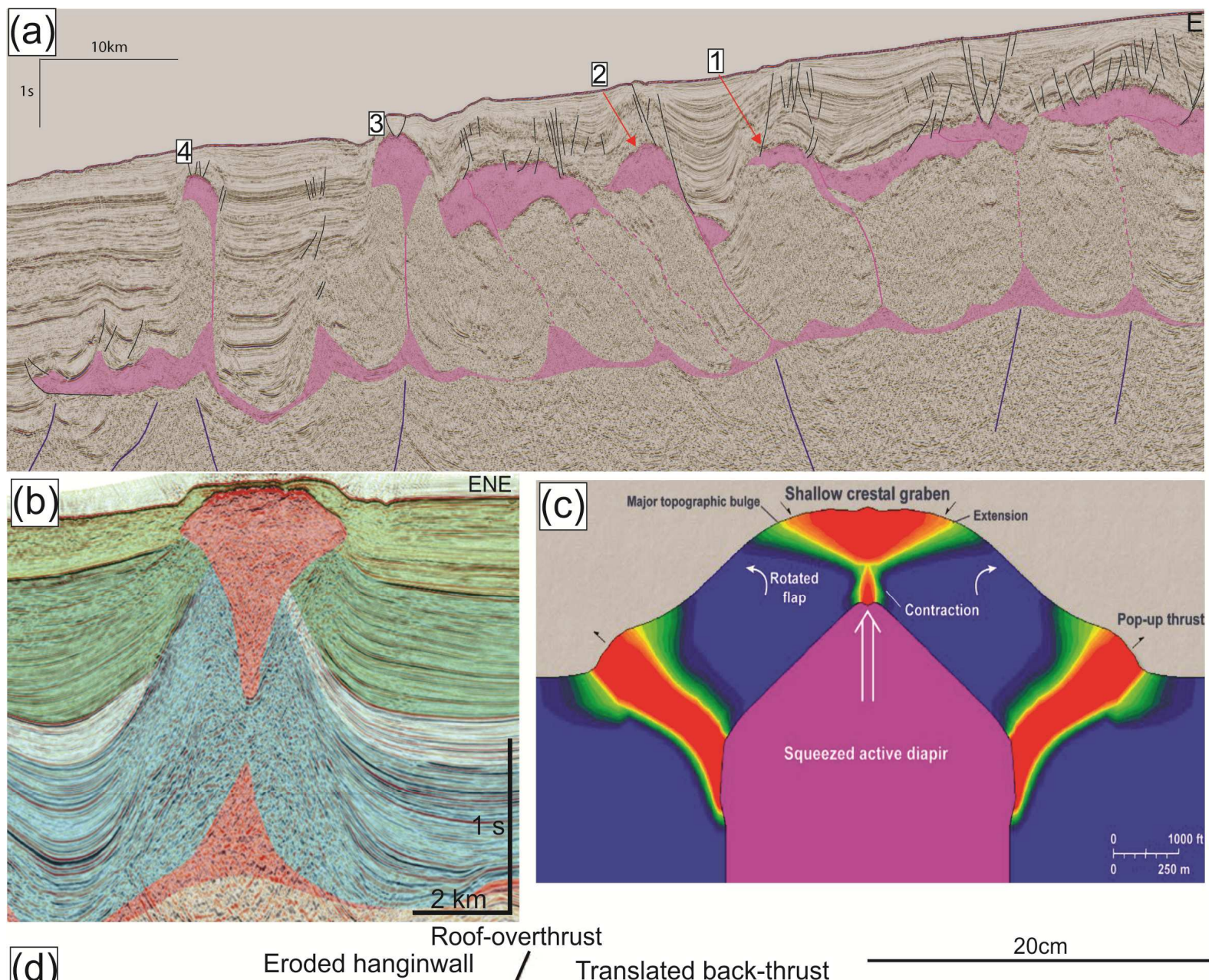

(d)

Translated back-thrust

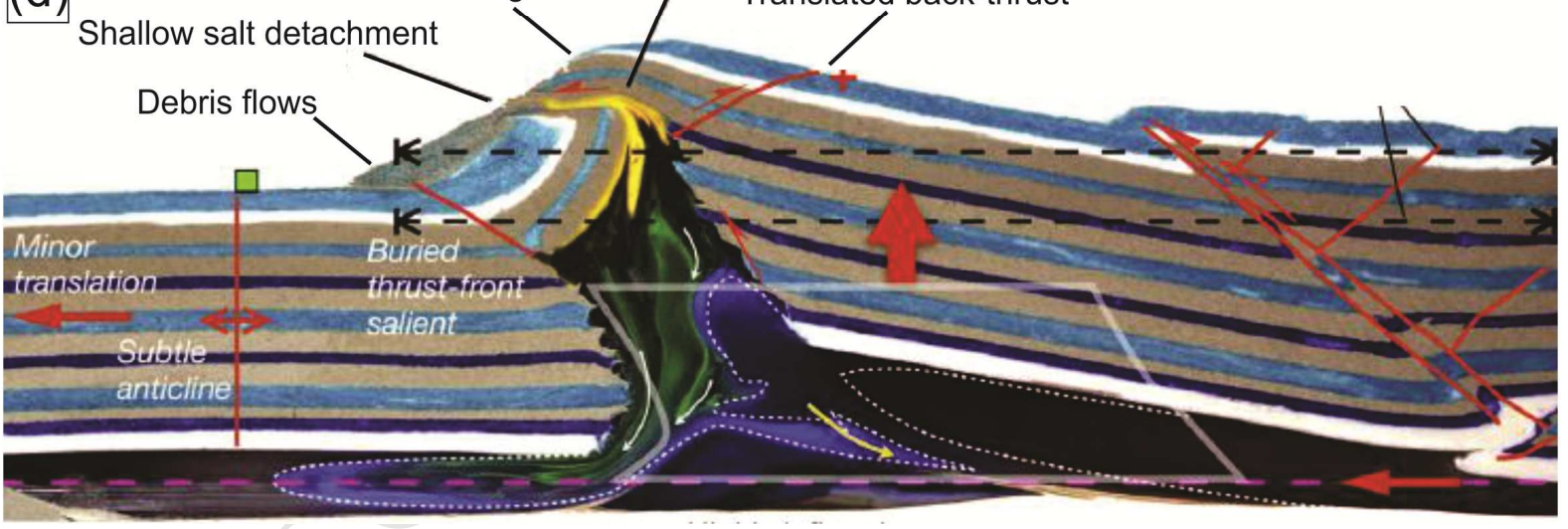

Figure 1: Examples of different scales of study and modelling of salt tectonics: (a) Regional seismic transect offshore Morocco showing allochthonous salt tongues (numbered from 1-4) and sheets, squeezed diapirs, a salt nappe and related sub-salt imaging problems; (b) example of squeezed teardrop diapir with intense roof arching and upturning, extracted from Hudec and Jackson (2011); (c); FEM of active salt piercement with salt in pink and zones of high-strain in green to red colours (Schultz-Ela et al., 1993); and (d) model of rejuvenation of buried salt stocks by shortening extracted from Dooley et al. (2009). 
a)

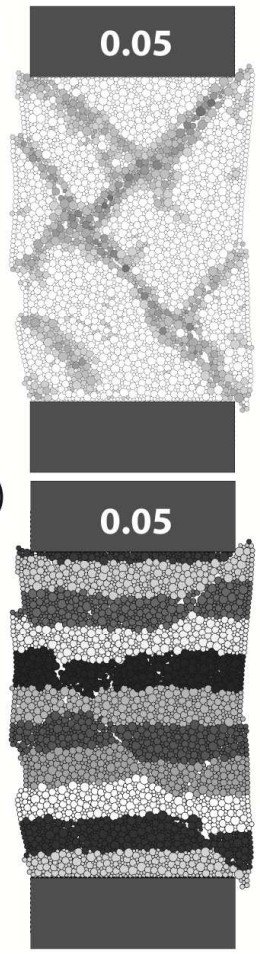

\subsection{1}

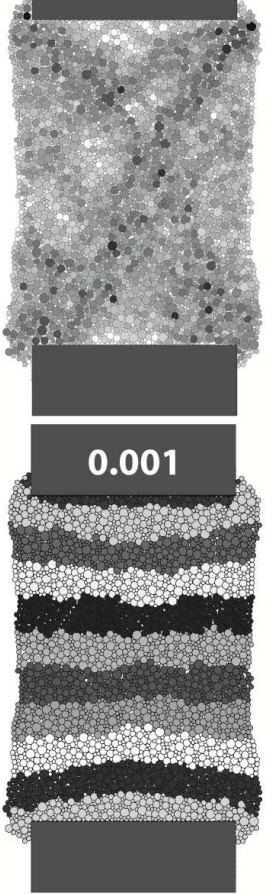

c)

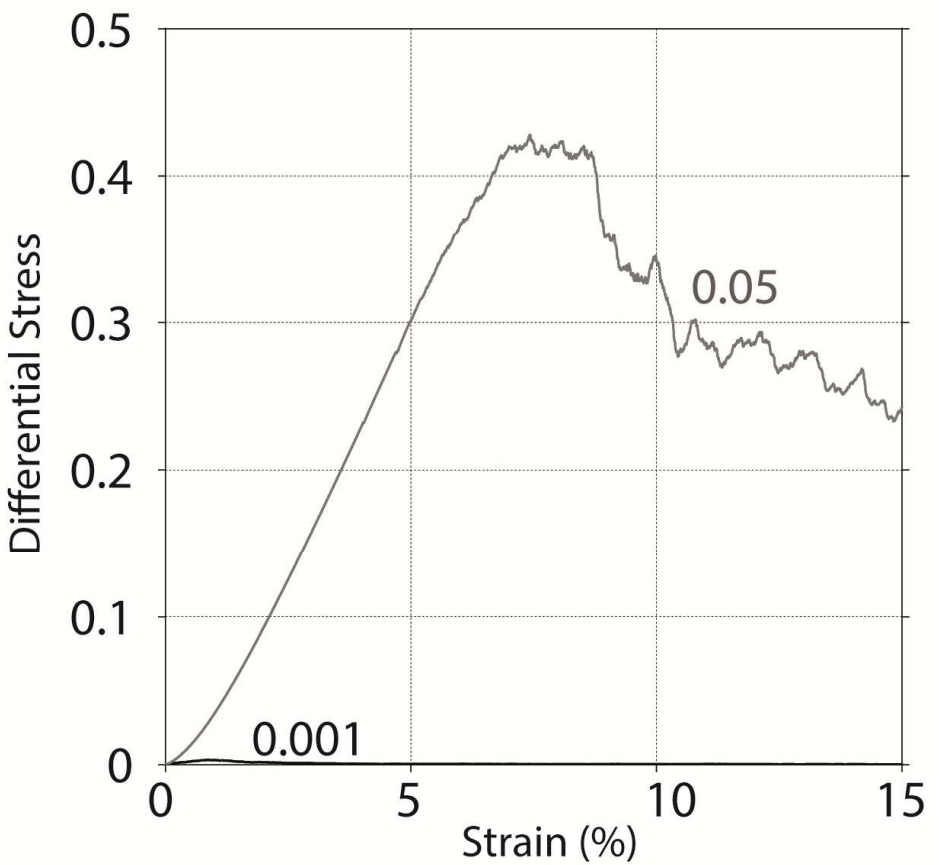

Figure 2: Biaxial compressional tests of materials used to model overburden (breaking separation of 0.05 ) and salt (breaking separation of 0.001). (a) Broken-bond plot after 15\% shortening where white indicates elements with no broken-bonds and black indicates elements with 9 broken-bonds. (b) The media after $15 \%$ of shortening. The white numbers on the upper plate represent the breaking separations. (c) The differential stress-strain relationship for this test showing a typical brittle response for the material used to model the overburden and a linear response of the material used for salt, which is representative of viscous-plastic behaviour. 


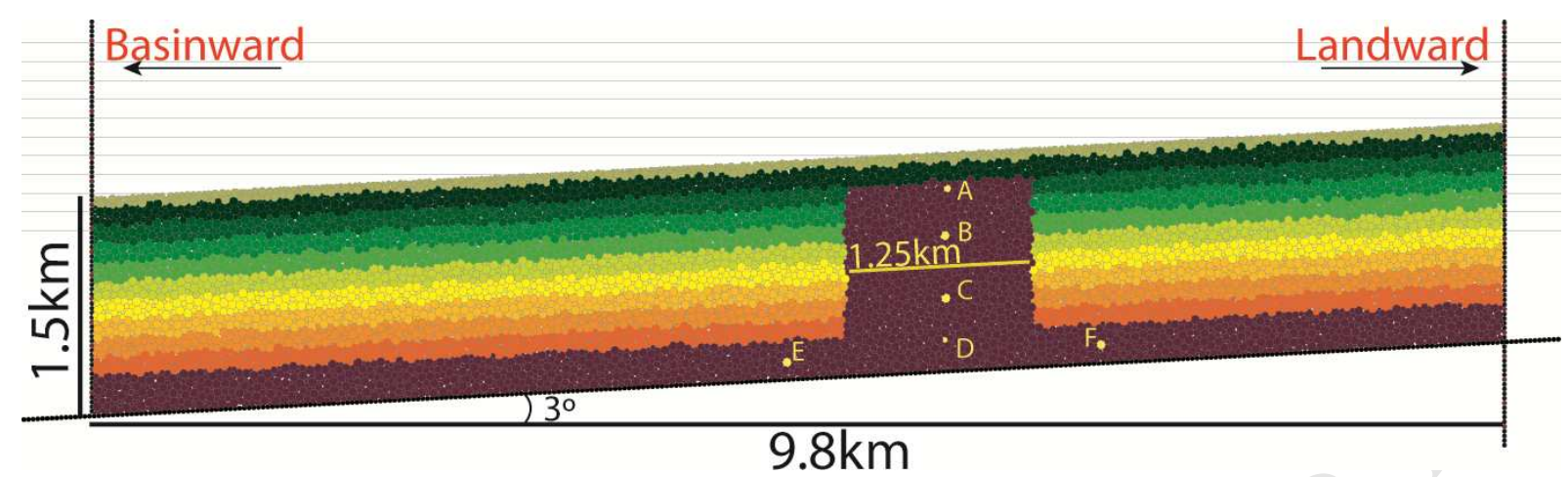

Figure 3: Initial input of the model with elements representing salt in brown. The box dips $3^{\circ}$ basinward and has a rectangular salt stock. For visualization purposes, the pre-kinematic cover has been divided into 10 coloured layers (oranges, yellows and greens) with no mechanical contrast between layers. Intra-salt markers are coloured in yellow and lettered A-D from top to bottom and $E$ and $F$ downdip and updip in the source-layer. 


\section{ACCEPTED MANUSCRIPT}
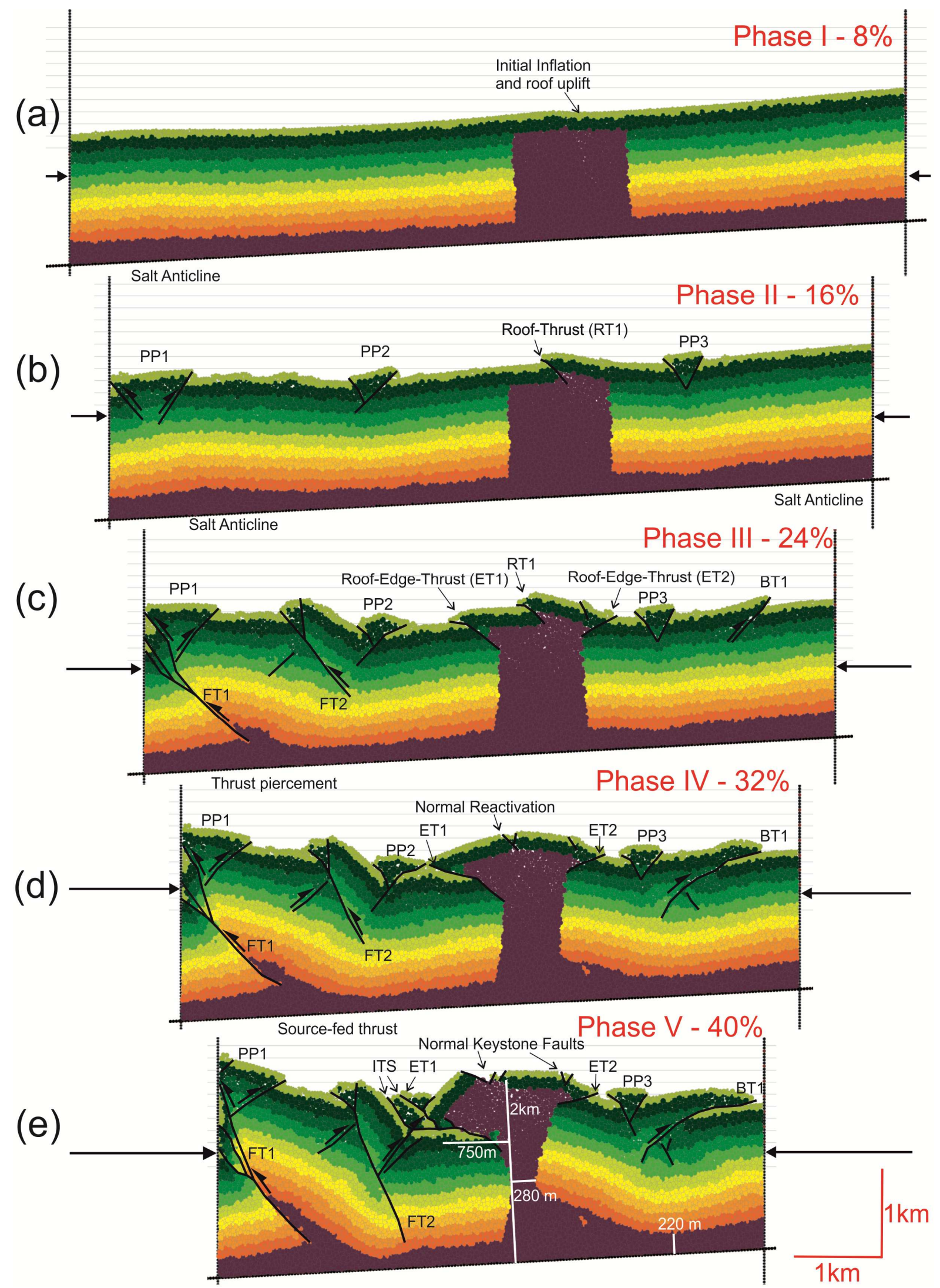

Figure 4: Results from Model 1 showing the sequential evolution of the system. Phases: (a) I, (b) II, (c) III, (d) IV and (e) V. Salt is coloured in brown, pre-kinematic layers are oranges, yellows and greens. Faults are represented by black lines and their sense of motion presented by a black arrow on the larger faults. Letters represent structures outlined in the text where: (RT) roof-thrusts; (ET) roof-edge-thrusts; (PP) pop-ups; (FT) front-thrusts; (BT) back-thrusts; and (ITS) imbricate thrustsystems. 


\section{ACCEPTED MANUSCRIPT}

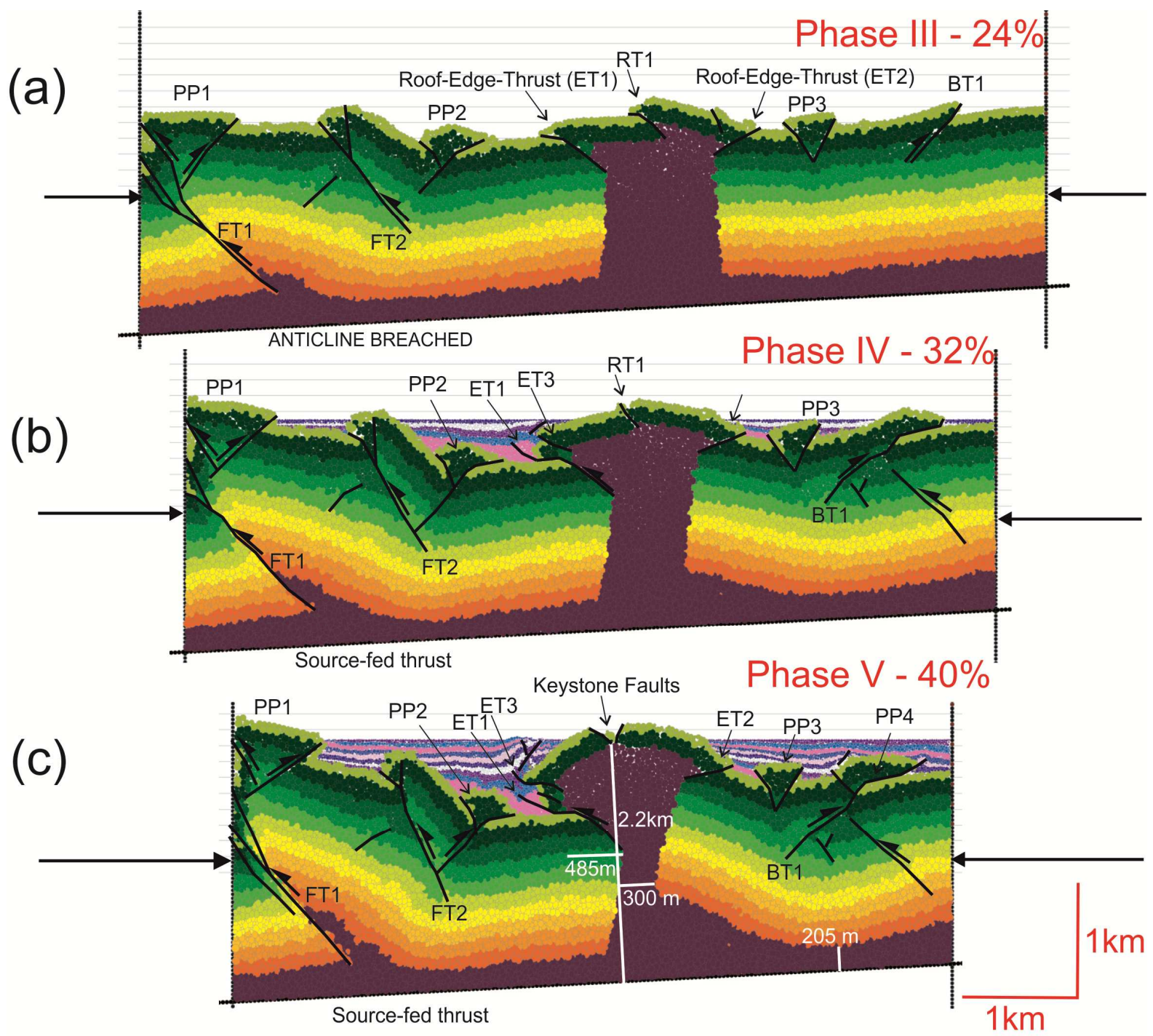

Figure 5: Results from Model 2 with the sequential evolution of the system after (a) Phase III, (b) IV and (c) V. Salt is coloured in brown and pre-kinematic layers are oranges, yellows and greens. Synkinematic sediments are represented by smaller radii elements and coloured in shades of pink, blue and white. Faults are represented by black lines and their sense of motion is represented by black arrows for the larger faults. Letters represent structures outlined in the text where: (RT) roof-thrusts; $(E T)$ roof-edge-thrusts; (PP) pop-ups; (FT) front-thrusts; and (BT) back-thrusts. 


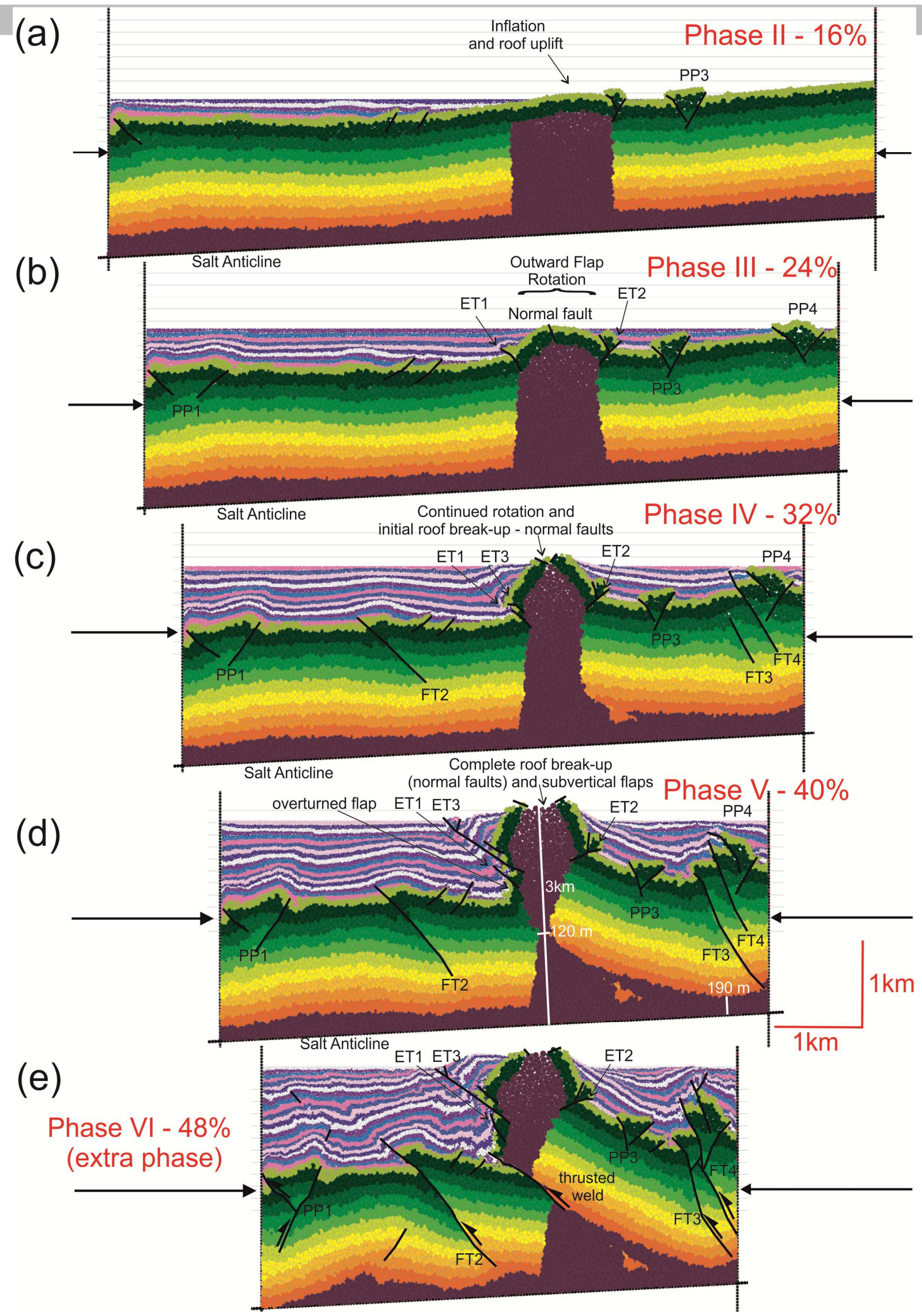

Figure 6: Results from model 3 with the sequential evolution of the system after Phases (a) II, (b) III, (c) IV, (d) V and an extra phase (e) VI. Salt is coloured in brown and pre-kinematic layers in oranges, yellows and greens. Syn-kinematic sediments are represented by smaller radii elements and coloured in shades of pink, blue and white. Faults are represented by black lines and their sense of motion is presented by black arrows on the larger faults. Letters denote structures outlined in the text where: (ET) roof-edge-thrusts; (PP) pop-ups; and (FT) front-thrusts. 


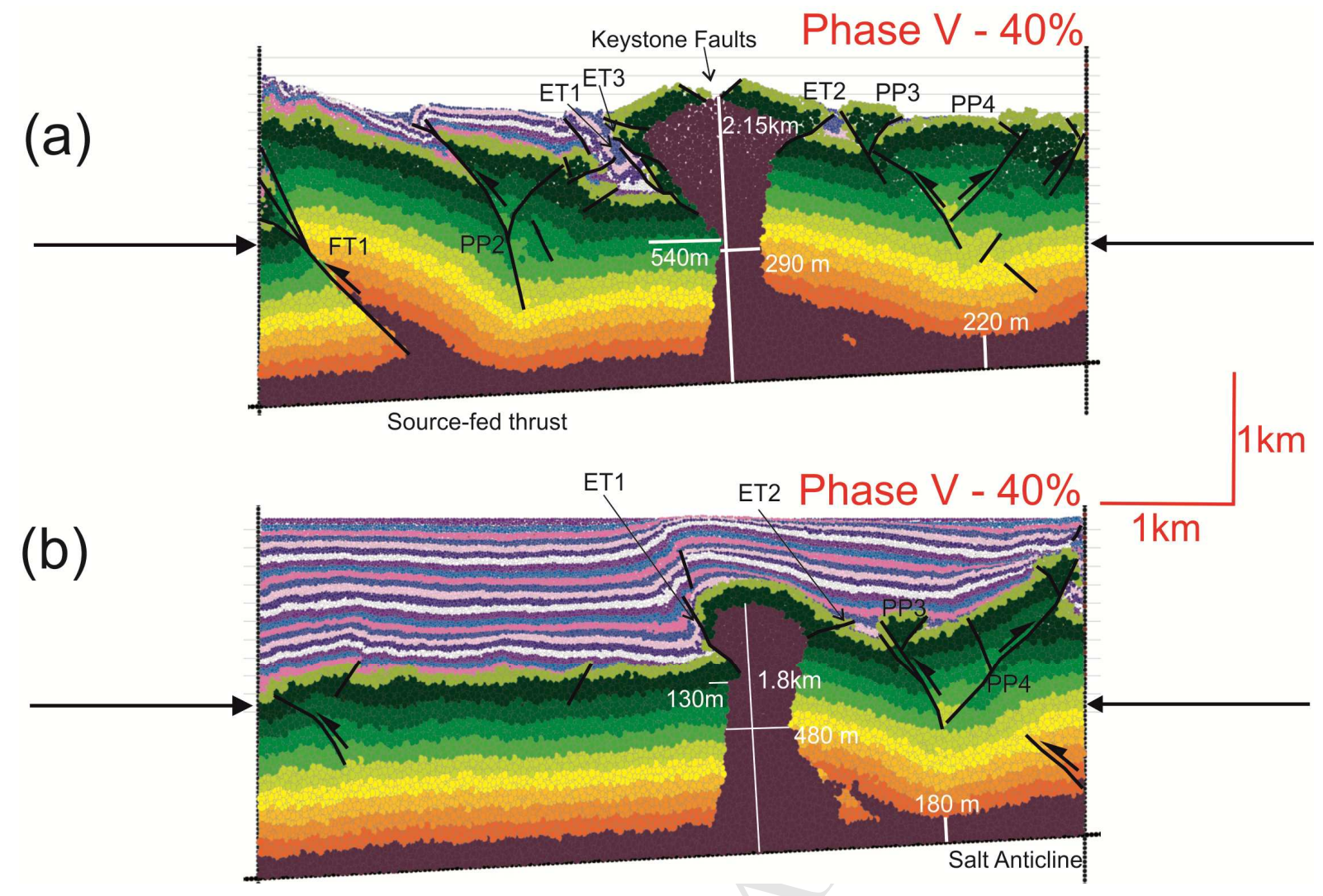

Figure 7: Final results (Phase V) with sedimentation added from Phases II-V for sedimentation rates of (a) $0.1 \mathrm{~m} / \mathrm{ka}$ (Model 4) and (b) $0.15 \mathrm{~m} / \mathrm{ka}$ (Model 5). Salt is coloured in brown and pre-kinematic layers are oranges, yellows and greens. Syn-kinematic sediments are represented by smaller radii elements and coloured in shades of pink, blue and white. Faults are represented by black lines and their sense of motion is represented by black arrows for the larger faults. Letters represent structures contained in the text where: $(E T)$ roof-edge-thrusts; (PP) pop-ups; and (FT) front-thrusts. 
(a)

2

3
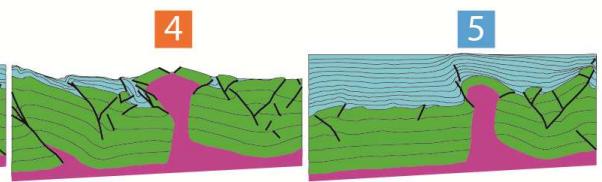

Models 1-3

(b) 3

$-1.5$
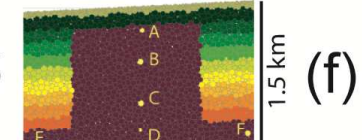

Models 3-5

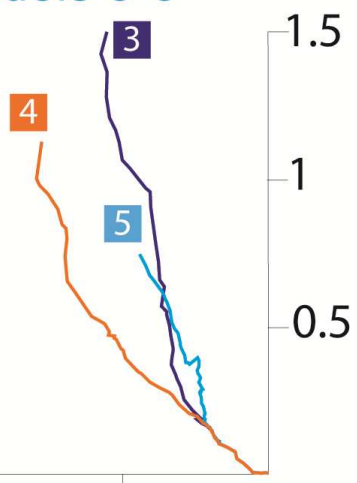

$\begin{array}{lll}1.5 & 1 & 0.5\end{array}$

(c)

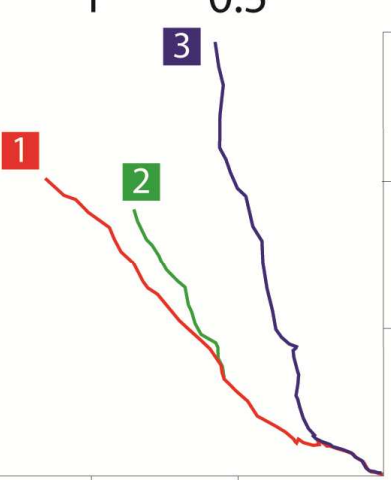

$-1.5$

Salt Stock

1

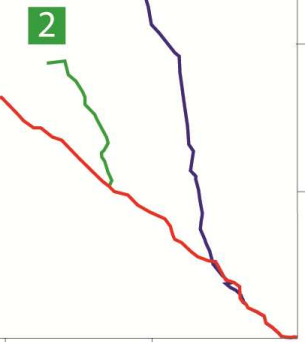

1

$-0.5$

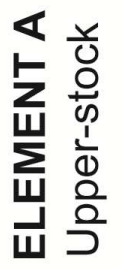

(f)

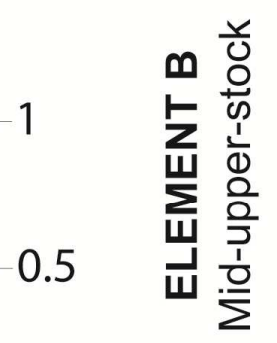

$\begin{array}{lll}1.5 & 1 & 0.5\end{array}$
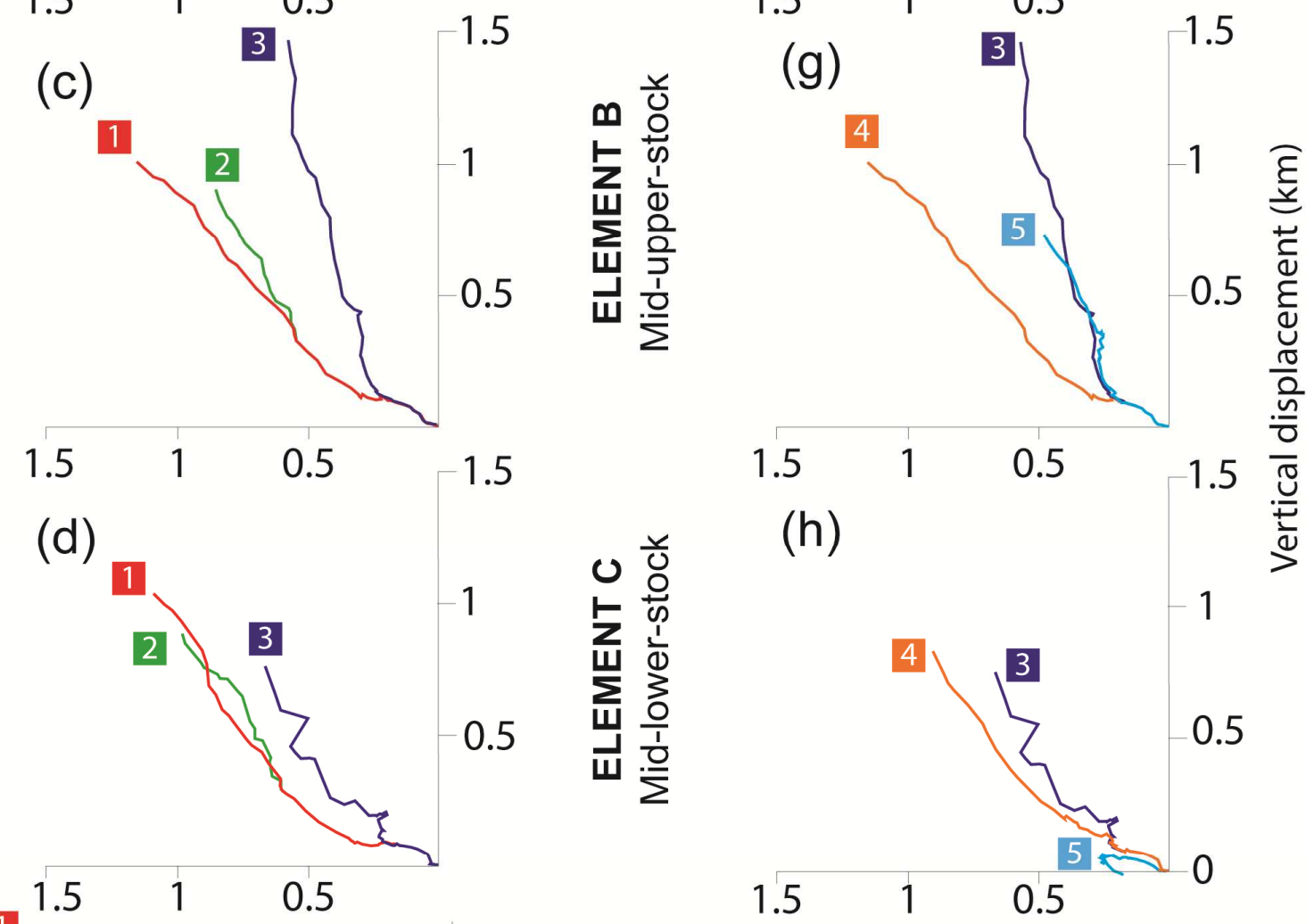

$-1.5$

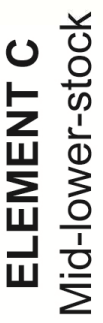

(i)

$$
\text { Scale } 3 x \text { larger }-0.25
$$

(e)
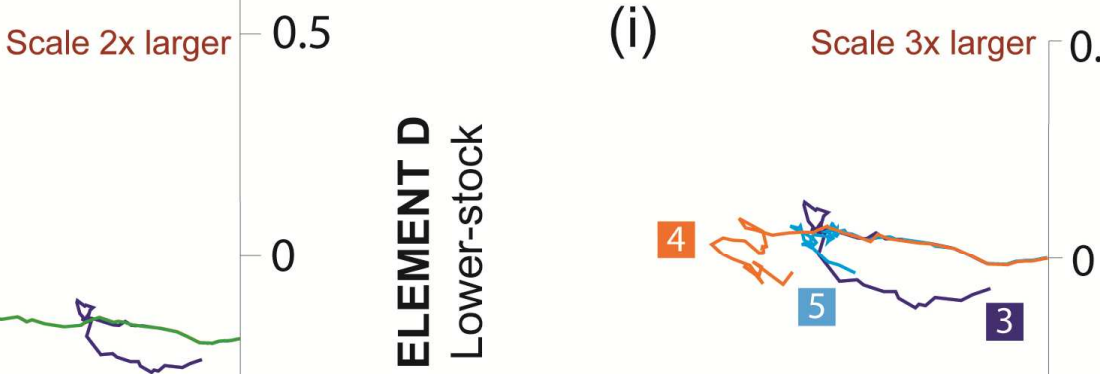

3

$\frac{0.75}{\text { Basinward }}$

$-0.5$

$0.5 \quad 0.25$

Horizontal displacement $(\mathrm{km})$

$-0.25$

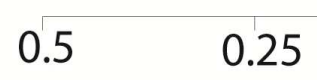

$\stackrel{\longrightarrow}{\longrightarrow}$

Figure 8 (a) Sketches of final structures within Models 1-5. Trajectories of Elements A-D within the salt stock are shown in (b) - (e) for Models 1-3 and (f) - (i) for Models 3-5. For clarity, trajectories for element $D$ (i) and (f) have exaggerated axes. 
Element E Basinward flank

(a)

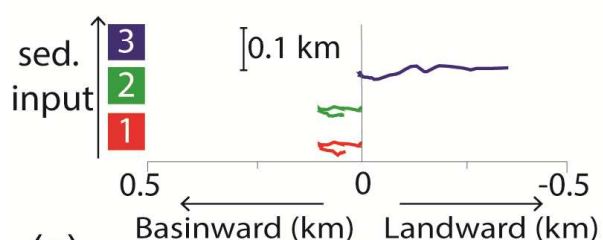

(c)

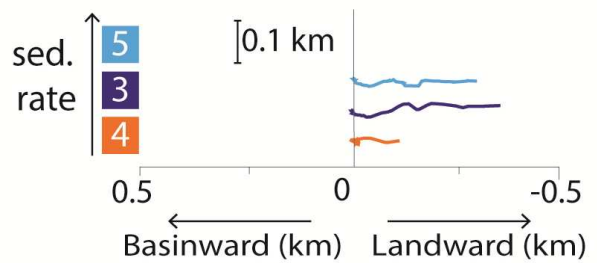

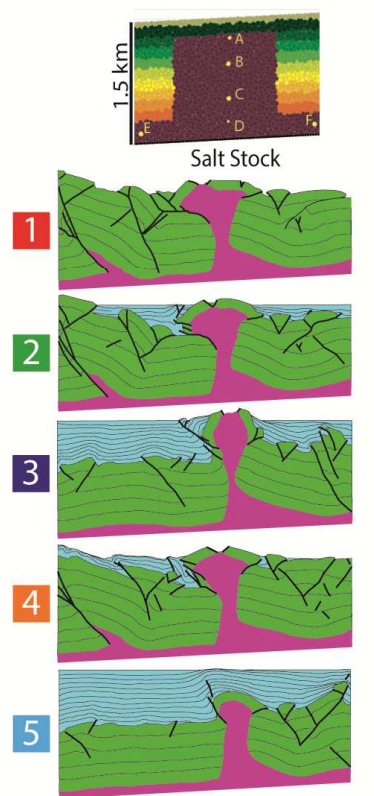

Element F

Landward flank

(b)

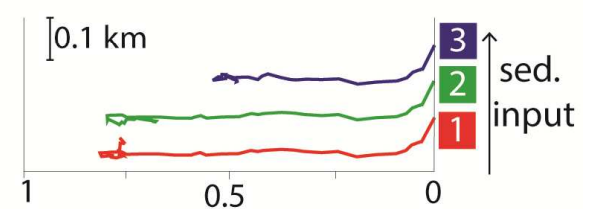

(d)

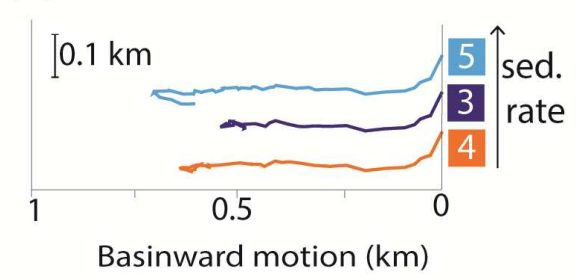

Figure 9: Trajectory of elements within the source-layer; Elements $E$ and $F$ (inset of original salt stock). The trajectories of elements $E$ and $F$ for Models 1-3 are shown in (a) and (b), respectively, and in (c) and (d) for Models 3-5. 

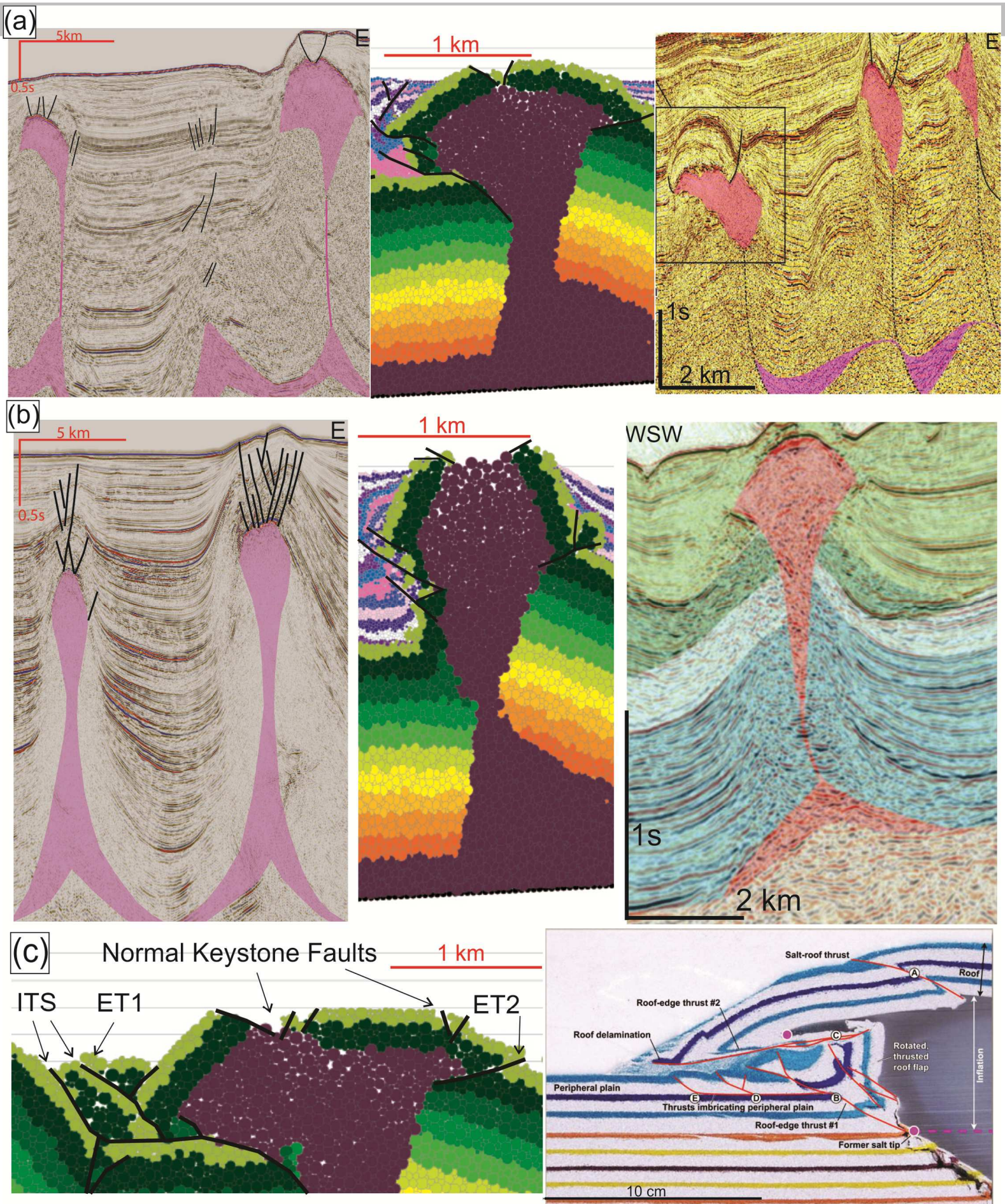

Figure 10: Comparison of model results with structures interpreted in seismic data and physical models. (a) Salt tongues with sub-vertical welded feeders offshore Morocco (left, courtesy of Chevron and ONHYM) and small salt tongues offshore Mauritania, adapted from Tari et al., 2017 (right) compare well to the salt and overburden geometries developed in Model 2 (centre); and (b) Upright squeezed diapirs offshore Morocco (left) and tear-drop diapir offshore Kwanza basin, adapted from Hudec and Jackson, 2011(right), both similar to the diapir developed in Model 3 (centre). (c) Close-up of salt tongue at Model 1 (left) showing similar faulting styles to a physical model of thrust-advance of a salt sheet extracted from Hudec and Jackson (2011), with roof uplift and rotation, and development of roof-edge thrusts and an imbricate thrust system at the downdip side of the structure. 


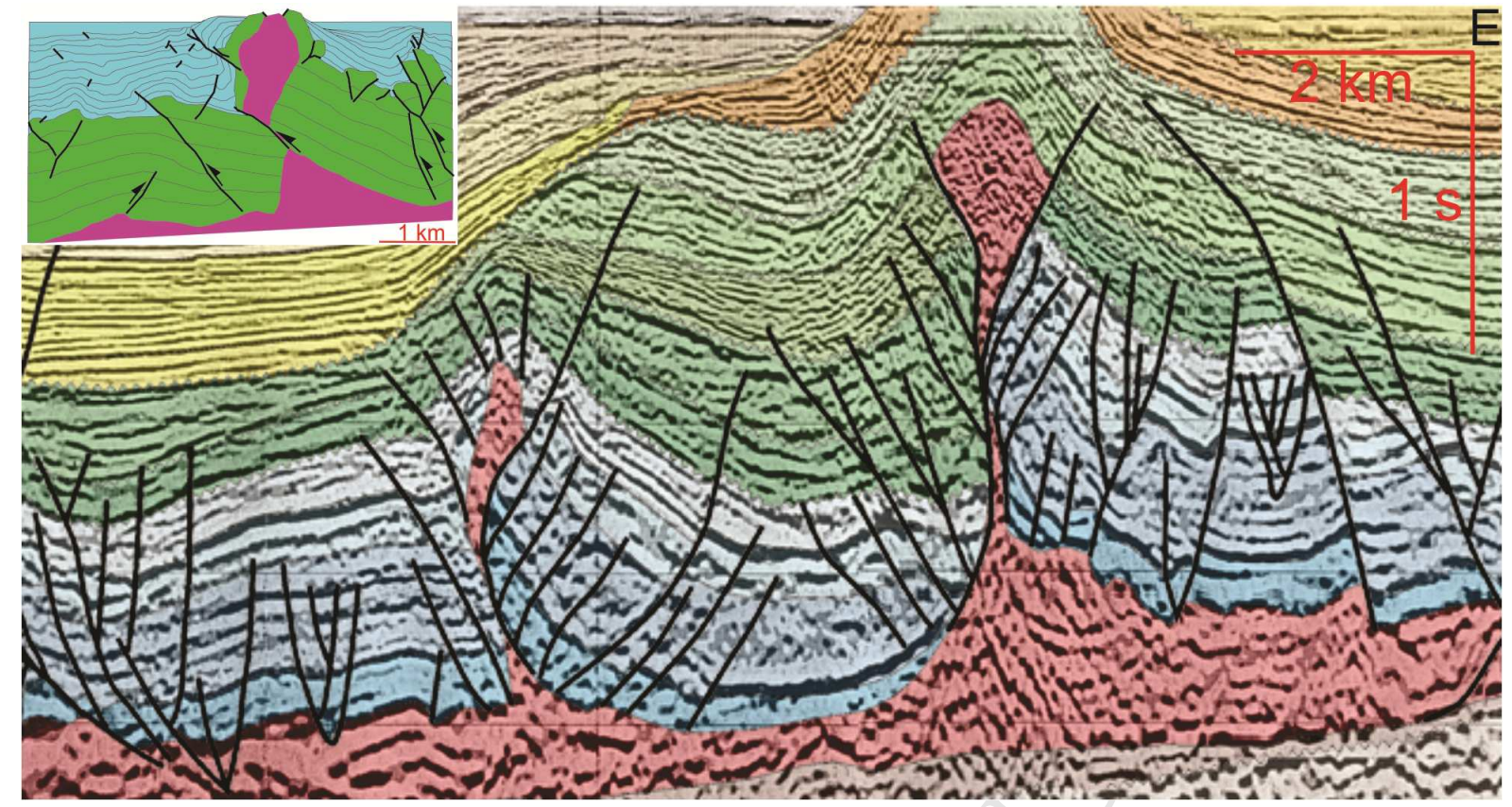

Figure 11: Interpreted seismic section of the Kwanza Basin, offshore Angola, extracted from Hudec and Jackson (2011), illustrating two squeezed and symmetric diapirs with intense roof overturn and considerable roof thrusting due to regional contraction. The tear-drop diapir to the west is separated from its pedestal by a basinward-vergent thrust-weld while the squeezed diapir to the east is still partially connected to its pedestal by a very thin feeder. Inset: Sketch of the additional phase of Model 3 (Fig. 6e) presented for comparison with the westernmost diapir. 


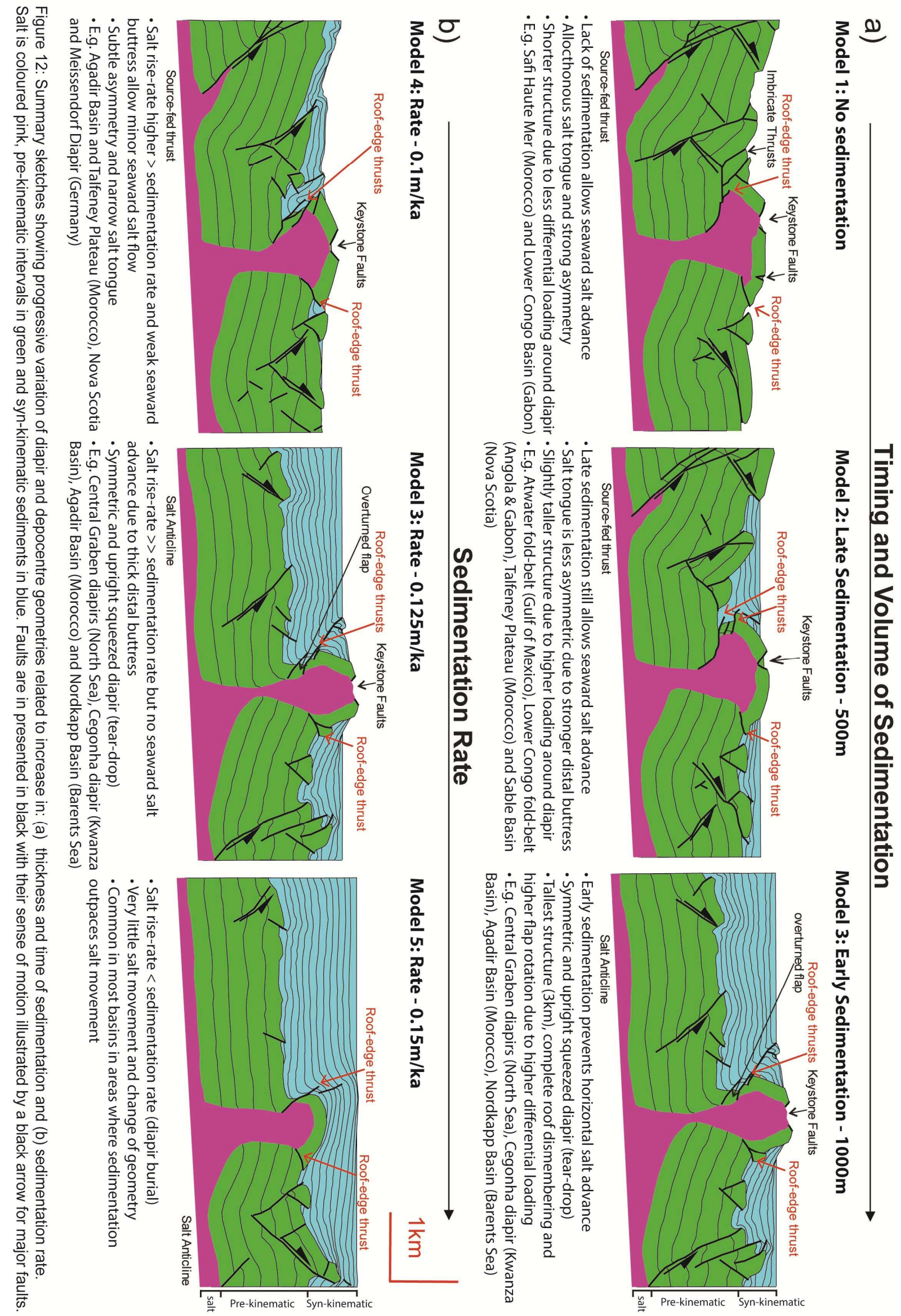



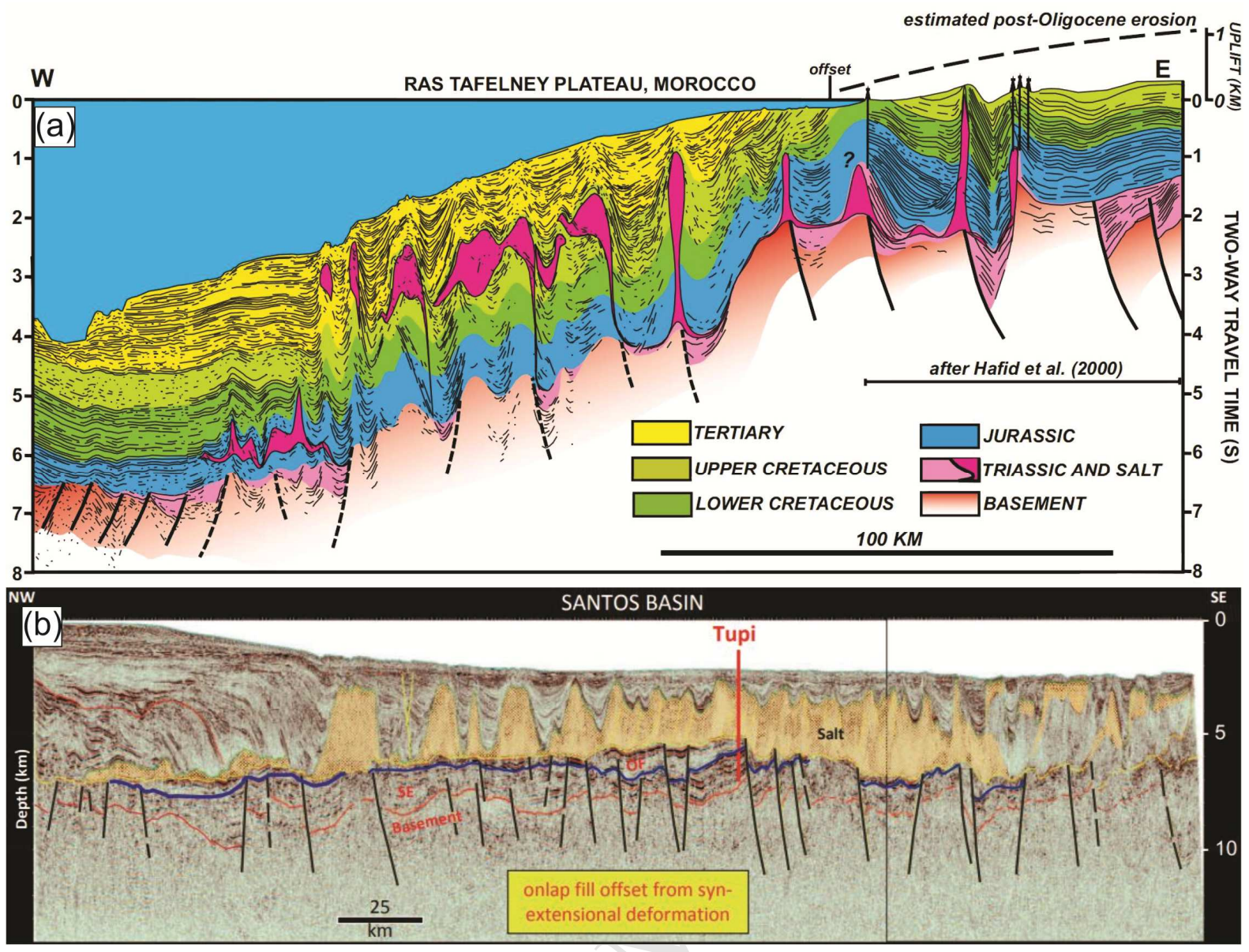

Figure 13: Seismic examples of variations of diapiric structural style along continental margins. (a) Line drawing cross-section offshore Essaouira Basin in Morocco showing symmetric and upright diapir geometries updip passing downdip into asymmetric and basinward-vergent diapirs and salt tongues (from Tari and Jabour, 2013). (b) Regional seismic section of the Santos Basin, offshore Brazil illustrating similar downdip variations of structural style, with symmetric upright diapirs and salt walls in a zone of thick and inflated salt, passing downdip to a zone characterized by basinward leaning diapirs and tongues (from Lentini et al., 2010). 


\section{Highlights}

Discrete-Element Modelling (DEM) of diapir shortening exhibit kinematics and geometries of active diapirism

Results attest efficiency of technique to model salt deformation driven by shortening

Time, rate and volume of sedimentation result in distinct squeezed diapir geometries

Results explain variations in salt-related structural styles of continental margins Method works as analytical guide to interplay of sedimentation and active diapirism 